\title{
Differentiating Immune Cell Targets in Gut-Associated Lymphoid Tissue for HIV Cure
}

\author{
Shahzada Khan,, ${ }^{1, *}$ Sushama Telwatte, ${ }^{2, *}$ Martin Trapecar,, ${ }^{1, *}$ Steven Yukl, and Shomyseh Sanjabi ${ }^{1,3}$
}

\begin{abstract}
The single greatest challenge to an HIV cure is the persistence of latently infected cells containing inducible, replication-competent proviral genomes, which constitute only a small fraction of total or infected cells in the body. Although resting $\mathrm{CD} 4^{+} \mathrm{T}$ cells in the blood are a well-known source of viral rebound, more than $90 \%$ of the body's lymphocytes reside elsewhere. Many are in gut tissue, where HIV DNA levels per million CD4 ${ }^{+} \mathrm{T}$ cells are considerably higher than in the blood. Despite the significant contribution of gut tissue to viral replication and persistence, little is known about the cell types that support persistence of HIV in the gut; importantly, $\mathrm{T}$ cells in the gut have phenotypic, functional, and survival properties that are distinct from $\mathrm{T}$ cells in other tissues. The mechanisms by which latency is established and maintained will likely depend on the location and cytokine milieu surrounding the latently infected cells in each compartment. Therefore, successful HIV cure strategies require identification and characterization of the exact cell types that support viral persistence, particularly in the gut. In this review, we describe the seeding of the latent HIV reservoir in the gut mucosa; highlight the evidence for compartmentalization and depletion of T cells; summarize the immunologic consequences of HIV infection within the gut milieu; propose how the damaged gut environment may promote the latent HIV reservoir; and explore several immune cell targets in the gut and their place on the path toward HIV cure.
\end{abstract}

Keywords: HIV cure, reservoir, latency, gastrointestinal tract, mucosa, T cells

\section{Introduction}

$\mathbf{C}$ OMBINATION ANTIRETROVIRAL THERAPY (ART) has transformed HIV/AIDS from a fatal disease to a chronic manageable illness in those who can maintain lifelong ARTmediated suppression of viremia. During the course of ART, the number of HIV DNA-harboring CD4 ${ }^{+} \mathrm{T}$ cells gradually declines in the blood over the first $1-4$ years, and then plateaus without further decline in subsequent years, ${ }^{1-3}$ thereby maintaining a remarkably stable pool of infected cells, including latently-infected cells that can rapidly contribute to viral rebound if treatment is interrupted.

Viral persistence in HIV-infected individuals on ART has classically been attributed to latently infected resting $\mathrm{CD} 4^{+} \mathrm{T}$ cells, ${ }^{4-7}$ which harbor integrated, replication-competent HIV and do not produce virus constitutively, but can be induced by activation to produce infectious virus. The latent proviral DNA is neither recognized by the immune system nor affected by ART. It is unclear what mechanisms govern HIV latency in vivo, and prior studies have implicated mechanisms such as inhibition of HIV transcriptional initiation, inhibition of transcriptional elongation, and post-transcriptional factors. ${ }^{8,9}$ Traditionally, it is believed that the latently infected cells transcribe little if any HIV RNA. However, cell-associated HIV RNA can be readily detected in blood and tissues of ART-suppressed patients. For example, one recent study using highly sensitive cell-associated HIV RNA and DNA single-genome sequencing revealed that some circulating $\mathrm{CD}^{+} \mathrm{T}$ cells from ART-suppressed patients express low levels (1-62 copies/cell) of HIV RNA. ${ }^{10}$ Further study is needed to determine if these findings from total $\mathrm{CD}^{+} \mathrm{T}$ cells are recapitulated in latently infected cells. However, latently-infected cells may show varying amounts of HIV transcription, including transcription of short, incomplete, or nonpolyadenylated HIV transcripts; newly developed digital droplet PCR assays that allow measurement of total

\footnotetext{
${ }^{1}$ Gladstone Institute of Virology and Immunology, Gladstone Institutes, San Francisco, California.

${ }^{2}$ San Francisco VA Health Care System and University of California, San Francisco (UCSF), San Francisco, California.

${ }^{3}$ Department of Microbiology and Immunology, University of California, San Francisco, San Francisco, California.

*These authors contributed equally to this work.
} 
and elongated HIV RNAs can also support these future studies. ${ }^{11}$

The mechanisms by which latency is established and maintained will likely depend on the location and cytokine milieu surrounding the latently infected cells. Therefore, it is critical to identify and characterize the exact cell types that support viral persistence in all anatomic compartments, including the gut. A recent study identified that CD32a ${ }^{+}$blood CD4 T cells isolated from ART-treated HIV $-1^{+}$participants are highly enriched for inducible replication-competent proviruses, ${ }^{12}$ suggesting CD32a as a potential marker for detecting latently infected cells. Given that the study only reported blood cells, further studies will be required to demonstrate the prognostic significance of CD32a in mucosal and lymphoid tissues. ${ }^{13}$ Importantly, HIV initiates and sustains a vicious inflammatory cycle by damaging the gastrointestinal (GI) tract, which leads to systemic exposure to gut microbial products, increased activation of $\mathrm{T}$ cells, and higher viral replication. ${ }^{14-16}$ Despite the significant contribution of gut tissue to viral replication and persistence, little is known about the cell types that support persistence of HIV in the gut.

In this review, we describe how HIV infection leads to depletion of T cells in the GI tract and discuss what is known about the HIV reservoir in the gut compared to other anatomic compartments. We give special consideration to the location and frequency of various subsets of human $\mathrm{T}$ cells in various lymphoid and mucosal tissues, as these will prove essential in HIV cure endeavors.

\section{Seeding the Latent HIV Reservoir in the Mucosa}

Most of our understanding of how the latent HIV reservoir is established comes from nonhuman primate models of simian immunodeficiency virus (SIV) infection and in vitro studies that use human cell culture systems. Upon mucosal SIV infection in rhesus macaques (RM), the viral reservoir is seeded very rapidly. ${ }^{17}$ Evidence from in vitro studies ${ }^{18}$ as well as HIV-infected individuals, ${ }^{19,20}$ indicates that the latent reservoir is also established very early in HIV infection. In agreement with these findings, initiation of ART as early as 10 days after the onset of symptoms of primary HIV-1 infection does not prevent generation of latently infected cells ${ }^{19}$; however, the size of latent reservoir can be limited by early administration of ART. ${ }^{1,21,22}$

Mathematical modeling also suggests that latency is established early and is hardwired into the HIV genome to enhance lentiviral transmission across the mucosa, especially when target cells are not abundant. ${ }^{23}$ Although the gut is rich with target cells, other factors in the mucosal milieu may contribute to rapid seeding of latently infected cells. For example, to establish a productive infection, HIV inhibits type I interferon (IFN) expression in T cells and macrophages. ${ }^{24}$ HIV blocks IFN production through protease sequestering of the cytoplasmic RNA sensor retinoic acid-inducible gene I (RIG-I). ${ }^{25}$ IFN resistance confers a distinct advantage to the transmitted viruses, creating a bottleneck at the mucosa and favoring selection of viruses that can replicate and spread efficiently in the face of a potent innate immune response. ${ }^{26}$ In vitro studies also support this model, as widespread defects in IFN-I responsiveness are observed within latently HIVinfected cell lines. ${ }^{27}$ Thus, latency may be established early after transmission to avoid an IFN-mediated inflammatory response, allowing the virus to surreptitiously traffic away from the mucosa and migrate into the lymphoid tissues, where IFN resistance promotes viral replication, while creating a target-rich environment in which the virus can spread.

Direct measurements of the latent reservoir in patients on ART using limiting dilution coculture (viral outgrowth) assays show variable, but extremely slow decay rates $\left(\mathrm{t}_{1 / 2}\right.$ of $6-44$ months) in resting $\mathrm{CD}^{+} \mathrm{T}$ cells in blood. ${ }^{28-32} \mathrm{In}$ addition, latently infected $\mathrm{CD} 4^{+} \mathrm{T}$ cells with memory phenotypes are long-lived and undergo homeostatic proliferation and clonal expansion, ${ }^{33,34}$ which may add to the prolonged persistence of HIV in these cells. ${ }^{35-37}$ Although residual viral replication may help replenish the latent reservoir in some patients, ${ }^{29,31}$ even without such replenishment, the half-life of the latent reservoir is sufficiently long that these cells will persist despite lifelong ART. Lower availability/penetration of drugs in lymphoid tissues ${ }^{38,39}$ and peripheral tissues, such as the gut and the central nervous system, may also contribute to possible residual replication in these anatomical sites. ${ }^{39-42}$ Low-level persistent production of HIV may, in turn, contribute to heightened immune activation, rendering cells more permissive to infection and helping replenish reservoirs of HIV-infected cells. ${ }^{31}$ Phenotypic identification of latently infected cells may greatly enhance innovative strategies to selectively target these cells in infected individuals, ${ }^{43}$ which would be a major milestone toward HIV cure.

\section{T-Cell Subsets: Phenotypes and Compartmentalization}

Memory T cells develop over decades in response to exposure to diverse antigens. By the second decade of life, memory $\mathrm{T}$ cells constitute up to $35 \%$ of circulating $\mathrm{T}$ cells. ${ }^{44}$ This pool of memory $\mathrm{T}$ cells reaches a plateau by the third decade of life and remains stable throughout adulthood. ${ }^{45,46}$ After antigen stimulation in lymphoid organs, naive $T\left(T_{N}\right)$ cells differentiate into activated effector cells that migrate to nonlymphoid tissues, where they act to clear the infection. A fraction of these cells persists as long-lived memory $\mathrm{T}$ cells that can be divided into three main subpopulations: central memory $\left(\mathrm{T}_{\mathrm{CM}}\right)$, effector memory $\left(\mathrm{T}_{\mathrm{EM}}\right)$, and tissue-resident $\left(\mathrm{T}_{\mathrm{RM}}\right.$ ) memory $\mathrm{T}$ cells (Table 1 ). $\mathrm{T}_{\mathrm{CM}}$ cells circulate between lymphatic tissues and blood, whereas $\mathrm{T}_{\mathrm{EM}}$ cells survey peripheral tissues and recirculate through the lymphoid system and the blood. A more recently identified subpopulation termed "transitional memory" $\mathrm{T}\left(\mathrm{T}_{\mathrm{TM}}\right)$ cells exhibits functional and transcriptional characteristics that are intermediate to $\mathrm{T}_{\mathrm{CM}}$ and $\mathrm{T}_{\mathrm{EM}}$. These $\mathrm{T}_{\mathrm{TM}}$ cells can be distinguished through their additional expression of $\mathrm{CD} 27$ receptor. ${ }^{47,48}$ The long-term circulating memory pool is maintained, in part, by memory stem cells $\left(\mathrm{T}_{\mathrm{SCM}}\right)$ that comprise $2 \%-4 \%$ of circulating memory $\mathrm{T}$ cells. ${ }^{49,50} \mathrm{~T}_{\mathrm{SCM}}$ exhibit a gene and cell surface molecule expression profile that place them phenotypically between $\mathrm{T}_{\mathrm{N}}$ and $\mathrm{T}_{\mathrm{CM} \cdot} \cdot{ }^{51,52} \mathrm{~T}_{\mathrm{SCM}}$ serve as precursors of other memory cells, ${ }^{53}$ but their cellular distribution in humans is poorly understood. In contrast to all these other memory $\mathrm{T}$-cell subsets, $\mathrm{T}_{\mathrm{RM}}$ cells reside in peripheral and mucosal tissues. They do not reenter circulation, but remain localized and poised for rapid effector function in sites not surveyed by $\mathrm{T}_{\mathrm{N}}$ and $\mathrm{T}_{\mathrm{CM}}$ cells. ${ }^{54,55}$

Most prior studies investigating various memory $\mathrm{T}$-cell subsets have focused on peripheral blood samples; however, more recent analyses of tissue biopsies and organ donors have 
Table 1. Surface Markers Expressed By CONVENTIONAL AND NONCONVENTIONAL T-Cell SubSETS

\begin{tabular}{|c|c|}
\hline Cell type & Surface marker \\
\hline \multicolumn{2}{|l|}{ CD4 $\mathrm{T}$ cell subsets } \\
\hline Naïve & 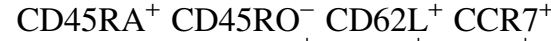 \\
\hline $\mathrm{T}_{\mathrm{CM}}$ & $\mathrm{CD}^{2} 5 \mathrm{RA}^{-} \mathrm{CD}^{4} \mathrm{RO}^{+} \mathrm{CCR}^{+} \mathrm{CD}^{+} 5^{+}$ \\
\hline $\mathrm{T}_{\mathrm{EM}}$ & $\begin{array}{l}\mathrm{CD}^{\mathrm{C}} 4 \mathrm{RA}^{-} \mathrm{CD}^{+} 5 \mathrm{RO}^{+} \mathrm{CCR}^{-} \mathrm{CD}^{-} \mathrm{L}^{-} \\
\mathrm{CD}^{+}\end{array}$ \\
\hline $\mathrm{T}_{\text {EMRA }}$ & $\mathrm{CD}^{2} 5 \mathrm{RA}^{+} \mathrm{CCR}^{-} \mathrm{CD}^{-} \mathrm{LL}^{-} \mathrm{CD} 27^{-}$ \\
\hline $\mathrm{T}_{\mathrm{RM}}$ & $\mathrm{CD}^{2} 5 \mathrm{RA}^{-} \mathrm{CD} 103^{+/-} \mathrm{CD}^{+} 9^{+}$ \\
\hline $\mathrm{T}_{\mathrm{TM}}$ & $\mathrm{CD}^{2} 5 \mathrm{RA}^{-} \mathrm{CCR}^{-} \mathrm{CD}^{-} 7^{+}$ \\
\hline $\mathrm{T}_{\mathrm{SCM}}$ & $\begin{array}{l}\mathrm{CD}^{2} 5 \mathrm{RA}^{+} \mathrm{CD}^{2} 5 \mathrm{R}^{+} \mathrm{CCR}^{+} \mathrm{CD} 28^{+} \\
\mathrm{CD}^{+} 5^{+} \mathrm{CD}^{+} \mathrm{CL}^{+}\end{array}$ \\
\hline $\mathrm{T}_{\mathrm{H}} 17$ & $\mathrm{CCR}^{+} \mathrm{CCR}^{+} \mathrm{CD}^{+} 61^{+}$ \\
\hline $\mathrm{T}_{\mathrm{H}} 22$ & $\mathrm{CCR}^{+} \mathrm{CCR}^{+} \mathrm{CCR} 10^{+}$ \\
\hline $\mathrm{T}_{\mathrm{FH}}$ & $\mathrm{CXCR}^{+} \mathrm{ICOS}^{+} \mathrm{PD}^{-1}{ }^{+-}$ \\
\hline $\mathrm{T}_{\text {reg }}$ & $\begin{array}{l}\mathrm{CD}^{4} \mathrm{RA}^{+} \mathrm{CD}^{+} 4 \mathrm{RO}^{-} \mathrm{CD}^{+} 5^{+} \\
\text {FOXP3 }^{+} \mathrm{CD}^{-} 27^{-}\end{array}$ \\
\hline \multicolumn{2}{|c|}{ Nonconventional $\mathrm{T}$ cells } \\
\hline$\gamma \delta \mathrm{T}$ cells & $\mathrm{CD}^{+}{ }^{+} \mathrm{TCR} \gamma \delta^{+}$ \\
\hline MAIT cells & $\begin{array}{l}\mathrm{CD}^{2} 5 \mathrm{RA}^{-} \mathrm{CD} 45 \mathrm{RO}^{+} \mathrm{CD}^{+} \mathrm{CD}^{+} 61^{+} \\
\mathrm{CD} 44 \text { high } \mathrm{CD} 27^{+}\end{array}$ \\
\hline \multicolumn{2}{|l|}{ ILCs } \\
\hline $\mathrm{EOMES}^{+} \mathrm{ILC}^{+}$ & $\mathrm{NKp}_{4}{ }^{+} \mathrm{CD} 6^{+} \mathrm{CD} 16^{+} \mathrm{CD} 4^{+} \mathrm{KIR}^{+}$ \\
\hline $\mathrm{EOMES}^{-} \mathrm{ILC}^{+}$ & $\mathrm{NKp} 6^{+} \mathrm{CD}^{2} 6^{+} \mathrm{CD} 161^{+} \mathrm{CD} 127^{+\prime-}$ \\
\hline $\mathrm{ILC}^{+}$ & $\begin{array}{l}\mathrm{CRTH}^{+} \mathrm{IL}_{-33 \mathrm{R}^{+}} \mathrm{CD}_{161^{+}} \mathrm{ICOS}^{+} \\
\mathrm{CD} 127^{+} \mathrm{CD} 117^{+/-}\end{array}$ \\
\hline $\mathrm{ILC}^{+}$ & $\mathrm{CD}_{16}{ }^{+} \mathrm{CD} 127^{+} \mathrm{CD} 117^{+}$ \\
\hline
\end{tabular}

$\gamma \delta \mathrm{T}$ cells, gamma-delta $\mathrm{T}$ cells; ICOS, inducible T-cell costimulator; ILCs, innate lymphoid cells; MAIT, mucosalassociated invariant $\mathrm{T}$.

advanced our understanding of the location and frequency of various subsets of human $\mathrm{T}$ cells in various lymphoid and mucosal tissues. ${ }^{46,56}$ Approximately half of the $\mathrm{CD} 4^{+} \mathrm{T}$ cells found in adult human blood have a naive phenotype. The proportions of $\mathrm{T}_{\mathrm{CM}}$ and $\mathrm{T}_{\mathrm{EM}}$ are similar in blood and peripheral lymph nodes, but most of the memory $\mathrm{T}$ cells found in various gut tissues display a $\mathrm{T}_{\mathrm{EM}}$ phenotype. ${ }^{46,57} \mathrm{~T}$ cells are highly diverse and compartmentalized among various tissue sites, ${ }^{4,58}$ and the effect of memory T-cell tissue compartmentalization should be considered in the context of identifying HIV reservoirs. Since the molecular mechanisms of HIV persistence could vary based on the phenotype of $\mathrm{HIV}$-infected cells and the prevailing tissue microenvironment, it is important to understand the frequency of cell subsets that harbor HIV DNA/RNA in all tissue types.

In contrast to blood, where most HIV DNA is found in central and transitional memory $\mathrm{CD}^{+}{ }^{+} \mathrm{T}$ cells, ${ }^{36}$ most HIV DNA and RNA in the gut are found in effector memory CD4 ${ }^{+}$ T cells. ${ }^{59}$ Although the gut contains a significant fraction of the body's memory $\mathrm{T}$ cells, most gut $\mathrm{T}$ cells also display markers of activation, suggesting that the mechanisms that maintain HIV in these cells are very different from those that maintain HIV latency in blood, where latently infected cells are primarily resting memory $\mathrm{CD} 4^{+} \mathrm{T}$ cells.

\section{T-Cell Subsets: The Gut Mucosa}

The GI tract, composed of a mucus layer, epithelial layer, and underlying lamina propria, constitutes a critical barrier that serves to regulate the uptake of nutrients, water, and electrolytes, while excluding and mediating appropriate responses to a plethora of potentially harmful substances and microbes. ${ }^{60}$ The GI tract contains the largest population of $\mathrm{T}$ lymphocytes, plasma cells, and macrophages in the human body, harboring up to $85 \%$ of all lymphoid tissue and over $90 \%$ of all lymphocytes. ${ }^{60,61}$ While both the small and large intestine are tightly connected with draining lymph nodes through the gut-associated lymphoid tissue (GALT), the small intestine is lined with organized lymphoid structures (including Peyer's patches), whereas the colon contains less structured lymphoid aggregates. ${ }^{62,63}$

Most intraepithelial lymphocytes (IELs) that reside in the epithelial layer are $\mathrm{CD}^{+} \mathrm{T}$ cells. However, $\mathrm{CD}^{+}{ }^{+} \mathrm{T}$ cells are not entirely absent from the epithelial layer, and their numbers increase toward the distal parts of the GI tract. ${ }^{63}$ While $\operatorname{TCR} \gamma \delta^{+}$cells are more abundant in the epithelium than in other parts of the body, they still represent a minor fraction of IELs. Unlike IELs, most $\mathrm{T}$ cells in the lamina propria are $\mathrm{CD} 4^{+} \mathrm{T}$ cells, which are present at an approximate ratio of 2:1 compared to $\mathrm{CD}^{+} \mathrm{T}$ cells. ${ }^{56}$ Several other populations of unconventional cells, such as invariant natural killer $\mathrm{T}$ cells, mucosal-associated invariant T (MAIT) cells, and innate lymphoid cells, also reside in the gut. ${ }^{63,64}$ While naive and $\mathrm{T}_{\mathrm{CM}} \mathrm{CD} 4^{+} \mathrm{T}$ cells constitute the largest populations in the blood, the gut contains primarily $\mathrm{T}_{\mathrm{EM}}$ and $\mathrm{T}_{\mathrm{TM}} \mathrm{CD} 4^{+} \mathrm{T}$ cells. ${ }^{65}$ The lamina propria harbors a diverse pool of $\mathrm{CD}^{+} \mathrm{T}$ cell populations, including IFN $\gamma^{+}\left(\mathrm{T}_{\mathrm{H}} 1\right)$, interleukin (IL)- $4^{+}$ $\left(\mathrm{T}_{\mathrm{H}} 2\right), \mathrm{IL}-17^{+}\left(\mathrm{T}_{\mathrm{H}} 17\right), \mathrm{IL}-22^{+}\left(\mathrm{T}_{\mathrm{H}} 22\right)$, and IFN $\gamma^{+}$and IL-17 $7^{+}$ $\left(\mathrm{T}_{\mathrm{H}} 1 / \mathrm{T}_{\mathrm{H}} 17\right)$ subsets, as well as forkhead box P3 (FoxP3)expressing regulatory $\mathrm{T}\left(\mathrm{T}_{\text {reg }}\right)$ cells producing IL-10.

$\mathrm{T}_{\mathrm{H}} 17$ and $\mathrm{T}_{\text {reg }}$ frequencies increase from the jejunum toward the colon, while frequencies of $C D 4^{+} \mathrm{T}_{\mathrm{H}} 1$ and $\mathrm{T}_{\mathrm{H}} 2$ cells remain similar through the GI tract. ${ }^{63}$ Within the germinal centers (GC) lies a population of $\mathrm{CD}^{+} \mathrm{CXCR}^{+} \mathrm{PD}^{+} 1^{+}$ lymphocytes, termed $\mathrm{T}$ follicular helper cells $\left(\mathrm{T}_{\mathrm{FH}}\right)$, which provide help to B cells during maturation, Ig class switching, and antibody hypermutation through secretion of IL-21 and other cytokines. ${ }^{66}$ Thus, the gut harbors a diverse array of $\mathrm{T}$ lymphocytes with both common and distinct phenotypic characteristics relative to $\mathrm{T}$ cells in other parts of the body.

\section{Depletion of Gut T Cells in Early HIV Infection}

The dramatic depletion of $\mathrm{CD}^{+} \mathrm{T}$ cells is one of the defining hallmarks of HIV infection. ${ }^{67}$ Studies in the pathogenic SIV model in RM suggest that during acute infection, the gut experiences a more rapid and severe depletion of $\mathrm{CD}^{+} \mathrm{T}$ cells than the peripheral blood, ${ }^{68}$ as a result of direct infection ${ }^{69}$ and indirectly due to apoptosis of infected and uninfected cells. ${ }^{70}$ In acutely infected humans, a dramatic depletion of $\mathrm{CD}^{+} \mathrm{T}$ cells in the gut is observed within 4-6 weeks ${ }^{71}$ and continues through all stages of the disease. ${ }^{67}$ In lymphoid tissues, $>95 \%$ of cell death may occur by Caspase-1 induced pyroptosis of abortively infected bystander $\mathrm{CD}^{+}{ }^{\mathrm{T}}$ cells. ${ }^{72}$ In contrast, circulating $\mathrm{CD}^{+} \mathrm{T}$ cells are resistant to HIV-induced pyroptosis, ${ }^{73}$ suggesting the existence of distinct mechanisms of $\mathrm{CD}^{+} \mathrm{T}$-cell depletion in lymphoid versus circulating cells. Whether a similar pyroptotic mechanism of cell death is also responsible for rapid depletion of gut $\mathrm{CD} 4^{+} \mathrm{T}$ cells is yet unknown.

At the mucosal portals of entry, HIV rapidly contacts the epithelium, antigen-presenting cells, and mucosal lymphocytes 
(Fig. 1). During the first hours of infection, HIV traverses the mucosal barrier into the lamina propria, where abundant $\mathrm{CD} 4^{+}$ memory $\mathrm{T}$ cells reside. Several factors contribute to the increased vulnerability of gut mucosal $\mathrm{CD}^{+} \mathrm{T}$ cells and their dramatic depletion soon after HIV infection. First, the rectum is lined with dendritic cells (DCs) abundant in DC-specific ICAM-3 grabbing nonintegrin (DC-SIGN), and HIV is selectively engulfed by these DC-SIGN ${ }^{+}$mononuclear cells, which are able to transfer the virus to $\mathrm{T}$ cells with a fourfold greater efficiency than DC-SIGN ${ }^{-}$cells. ${ }^{74}$

Secondly, compared to $\mathrm{CD}^{+} \mathrm{T}$ cells in the blood, a much higher percent of gut $\mathrm{CD}^{+} \mathrm{T}$ cells expresses markers of memory (CD45RO) ${ }^{75}$ and the HIV coreceptor CCR5. ${ }^{76-80}$ Consequently, depletion of $\mathrm{CD}^{+}{ }^{+} \mathrm{T}$ cells in the GI tract occurs predominantly in $\mathrm{CCR}^{+} \mathrm{CD}^{+}{ }^{+} \mathrm{T}$ cells, ${ }^{67}$ with those exhibiting a memory phenotype being most readily infected ${ }^{81-84}$ and depleted, ${ }^{70}$ while $\mathrm{CD} 4^{+}$-naive T cells are infected at a significantly lower frequency ${ }^{82}$ and are relatively spared. ${ }^{84}$ In vitro data also indicate that intestinal epithelial cells may select and transfer CCR5-tropic HIV-1 by transcytosis across the tight epithelial cell monolayer, ${ }^{85}$ which might contribute to the predominance of R5-tropic HIV during acute primary infection. ${ }^{86,87}$

Third, much of the expansive surface area of the GI mucosa endures constant exposure to microbial antigens, resulting in a constant state of immunologic activation, which is characterized by high levels of HIV-1 stimulatory chemokines and proinflammatory mediators. ${ }^{88}$

Fourth, expression of the surface receptor $\alpha 4 \beta 7$ integrin, which mediates lymphocyte homing to mucosal sites, can also enhance binding to HIV Envelope protein on viral particles, leading to an increase in $\mathrm{CD} 4^{+}$T-cell susceptibility to infection. ${ }^{89}$ In par with these observations, a recent study in SIVinfected monkeys found that neutralizing antibody $(\mathrm{Ab})$ to $\alpha 4 \beta 7$ significantly lowered detectable viral load in plasma. ${ }^{90}$ Further evidence suggested that integrin $\alpha 4 \beta 7$ can be incorporated into circulating virions, enabling the virion- $\alpha 4 \beta 7$ complex to bind to mucosal addressin cell adhesion molecule- 1 (MAdCAM-1)-expressing cells to enhance infection, ${ }^{91}$ which could be a potential mechanism of anti- $\alpha 4 \beta 7 \mathrm{Ab}$-mediated reduction in plasma viral load in infected monkeys. ${ }^{90}$ The effect of the $\alpha 4 \beta 7$ neutralizing Ab on gut as well as other mucosal or lymphoid tissue infection is yet unknown.

Finally, recent in vitro evidence suggests that HIVmediated changes in the gut microbiome could result in lipopolysaccharide-induced upregulation of CCR5, which in turn could increase T lymphocyte susceptibility to HIV and serve to increase CCR5-tropic HIV-1 production. ${ }^{92}$ Together, these factors contribute to the increased susceptibility of $\mathrm{CD}^{+} \mathrm{T}$ cells to initial and ongoing infection, permitting higher levels of infection and viral replication in the gut.

\section{Disruption of the Gut Barrier and Immunologic Sequelae During Chronic HIV Infection}

HIV infection results in the marked disruption of the three major components of the GI tract: the microbial barrier, composed of commensal intestinal flora; the immunologic barrier, comprising intramucosal lymphocytes, mesenteric lymph nodes, and secreted factors responsible for mediating the host immune response; and the mechanical barrier formed by epithelial and endothelial cells connected by tight junctions. ${ }^{93}$ Intestinal barrier dysfunction and subsequent immune activa- tion coincide with HIV-mediated depletion of $\mathrm{CD}^{+} \mathrm{T}$ cells and result from the destruction of tight junctions between the single layer of epithelium that lines the vast mucosal surfaces of the GI tract, leading to enhanced microbial permeability (Fig. 1). ${ }^{16,94}$ The compromised structural integrity of the mucosal barrier facilitates translocation of microbial products, which significantly contribute to immune activation during chronic infection ${ }^{16,95}$ and may also result in delayed reconstitution of $\mathrm{CD}^{+}{ }^{+}$T cells. ${ }^{96}$ Microbial translocation can be further exacerbated by intestinal microbiota that degrades tryptophan through the kynurenine pathway, contributing to the dysfunction of gut mucosal CD4 ${ }^{+} \mathrm{T}_{\mathrm{H}} 17$ and $\mathrm{T}_{\mathrm{H}} 22$ cells. ${ }^{97,98}$

Systemic immune activation arising from gut barrier dysfunction has wide-ranging, mostly deleterious consequences. Chronic immune activation is multifaceted, driven by polyclonal B-cell activation, ${ }^{99}$ increased T-cell activation ${ }^{100}$ and turnover, ${ }^{101}$ and dysregulation of cytokine production. ${ }^{102} \mathrm{~A}$ high turnover of $\mathrm{CD}^{+}$and $\mathrm{CD}^{+} \mathrm{T}$ cells disrupts $\mathrm{T}$-cell homeostasis and contributes to lower overall half-lives of these cells. ${ }^{103,104}$ This turnover perpetuates HIV infection by generating more viral targets through the production of $\mathrm{CD}^{+}$ $\mathrm{T}_{\mathrm{EM}}$ cells from $\mathrm{T}_{\mathrm{CM}}$ cells, ${ }^{84}$ ultimately resulting in depletion and exhaustion of memory T-cell pools. Sustained immune activation may also contribute to decreased thymic function over time. ${ }^{105,106}$ In addition, collagen deposition and the ensuing fibrosis of lymphatic tissues create an unfavorable microenvironment for $T_{N}$ cell survival and hinders immune reconstitution with ART. ${ }^{67,107,108}$ Moreover, decreases in digestion and absorption result from aberrant expression of genes regulating lymphocyte activation, inflammation, lipid and carbohydrate metabolism, active transport, and epithelial barrier maintenance. ${ }^{109}$

The profound HIV-mediated damage to the GI tract may also contribute to a multitude of vascular, liver, renal, cardiac, and pulmonary comorbidities that are not remedied by ART. ${ }^{110,111}$ Even after years on ART, the absolute number of $\mathrm{CD} 4^{+} \mathrm{T}$ cells in the gut tissues of HIV-infected individuals is not restored to the levels observed in noninfected individuals, ${ }^{67,71,112,113}$ and gut $\mathrm{CD} 4^{+} \mathrm{T}$-cell reconstitution lags behind that in the blood. ${ }^{71,114}$

\section{The Damaged Gut Environment Promotes Latent HIV Reservoir}

Multiple studies in both untreated and ART-treated patients report that HIV levels are higher in the gut versus the blood. In untreated patients, levels of HIV p24 antigen are much higher in intestinal biopsies than in blood. ${ }^{115}$ Although $\mathrm{CD}^{+} \mathrm{T}$ cells constitute a much smaller percent of the total mononuclear cells in the gut, compared to peripheral blood, gut HIV DNA levels per million total cells are comparable to $^{115}$ or greater than those in the blood ${ }^{116}$ of untreated patients, while HIV DNA and RNA per million $\mathrm{CD}^{+} \mathrm{T}$ cells are 13- and 10-fold higher (respectively) in the colon compared to the blood of untreated patients ${ }^{117}$ (Table 2).

HIV RNA, HIV DNA, and infectious virus have been detected in the gut of ART-suppressed patients, and some cross-sectional studies found little difference between ARTtreated and ART-untreated patients in HIV detection frequencies or nucleic acid levels. ${ }^{118-120}$ A prospective study found that initiation of ART during early infection caused similar reductions in HIV RNA in blood and rectum at 6 


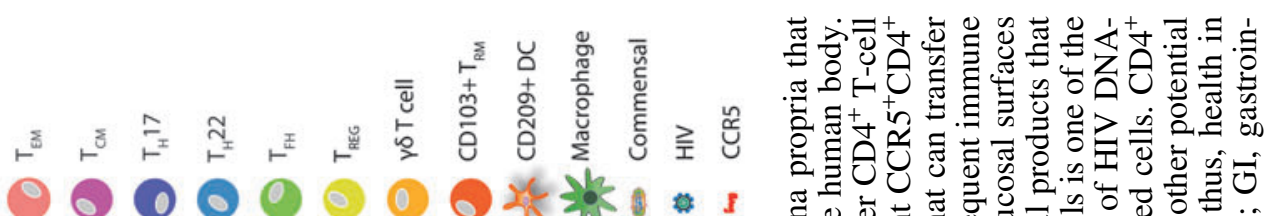

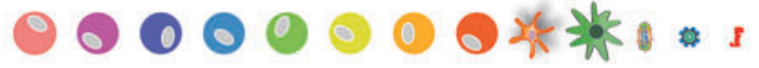

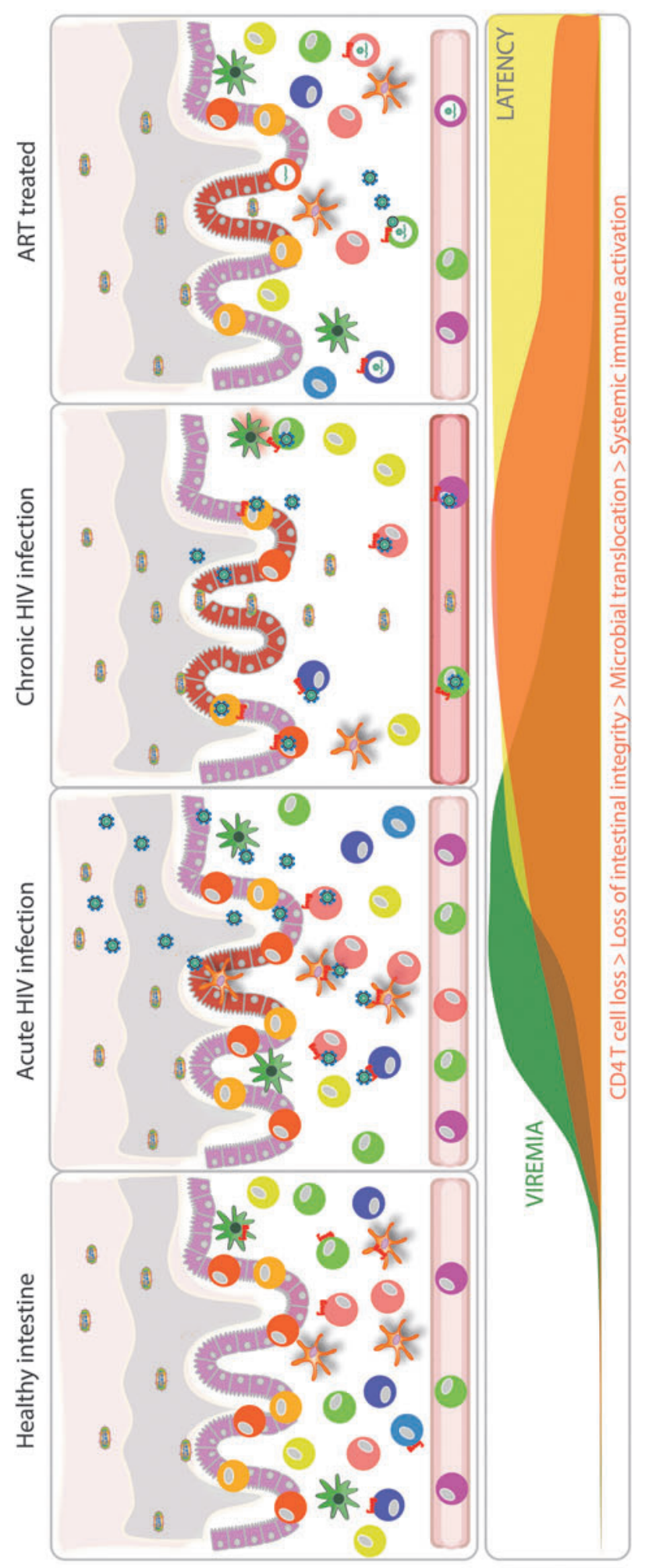

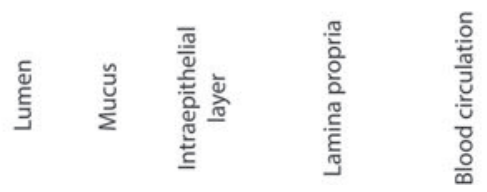

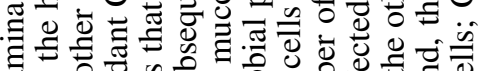

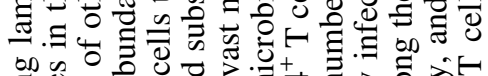

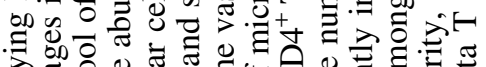

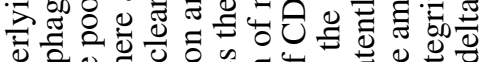

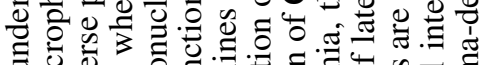

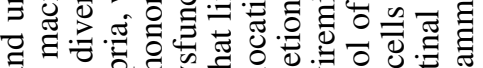
ส

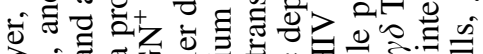

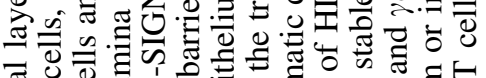

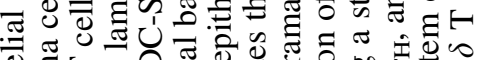
ฮ

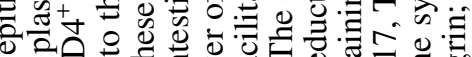

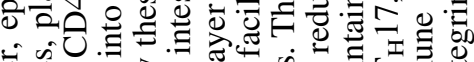
过

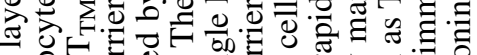

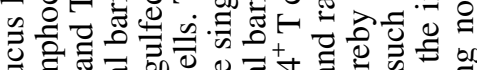

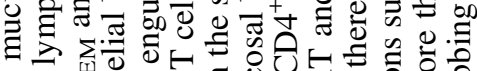

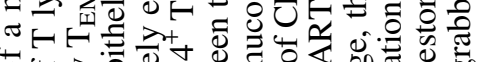

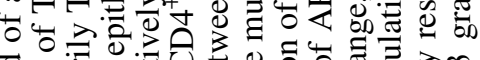
व

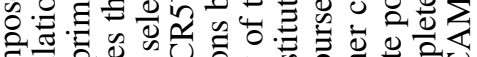
혈.

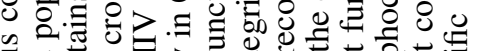

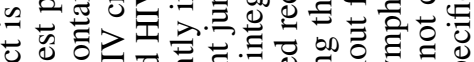

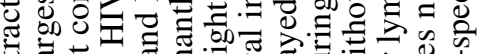

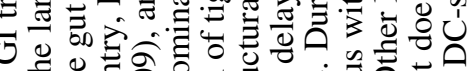

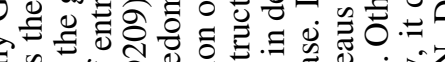

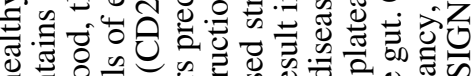

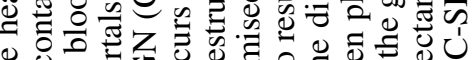

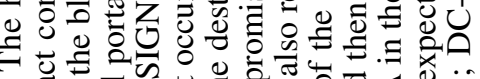

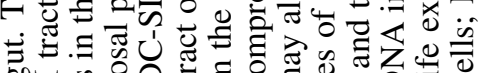

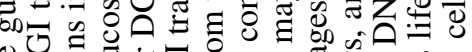

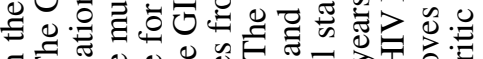

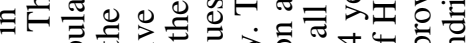

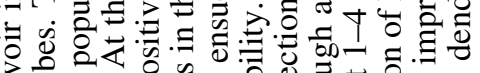

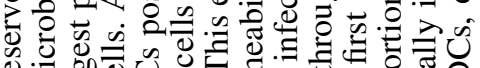

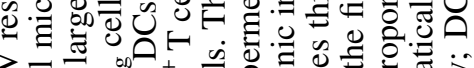

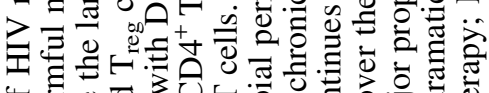

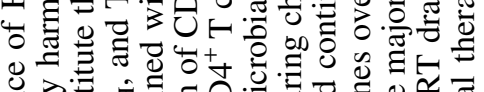

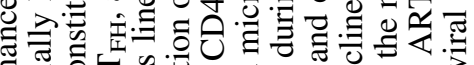

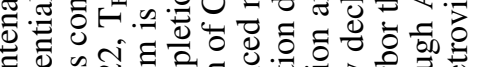

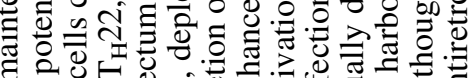

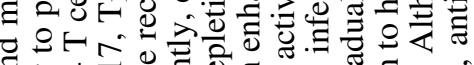

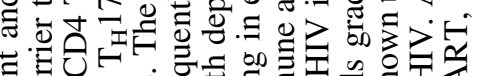

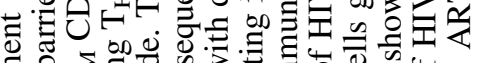

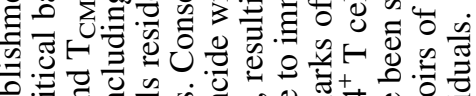

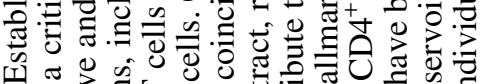

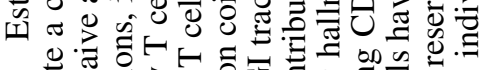
-

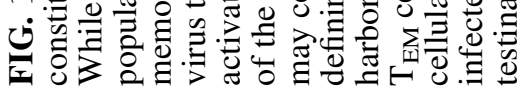


Table 2. HIV Levels in the Gut Versus in the Blood

\begin{tabular}{|c|c|c|}
\hline Finding & $\begin{array}{l}\text { Treatment } \\
\text { status }\end{array}$ & Reference \\
\hline Levels of HIV p24 antigen are much higher in intestinal biopsies than in blood & Untreated & 115 \\
\hline Gut HIV DNA levels per million total cells are comparable or greater than those in the blood & Untreated & 115,116 \\
\hline $\begin{array}{l}\text { HIV DNA and RNA per million } \mathrm{CD}^{+} \mathrm{T} \text { cells are } 13 \text { - and } 10 \text {-fold higher (respectively) in the } \\
\text { colon compared to the blood }\end{array}$ & Untreated & 117 \\
\hline HIV DNA levels per million CD4 ${ }^{+} \mathrm{T}$ cells are higher in the gut than blood & ART & 122,123 \\
\hline $\begin{array}{l}\text { Levels of HIV DNA and unspliced HIV RNA per million CD } 4^{+} \text {T cells are higher in four } \\
\text { different gut sites than in blood; gut contains } 1.2 \times 10^{9} \text { infected CD } 4^{+} \mathrm{T} \text { cells, or up to } 95 \% \\
\text { of all HIV-infected cells in the body; median HIV RNA/DNA ratio lower in the gut } \\
\text { (except ileum) than that in the blood, suggesting that gut sites other than } \\
\text { ileum have more "latently" infected cells }\end{array}$ & ART & 124 \\
\hline Gut contains twice as many HIV DNA ${ }^{+}$cells as blood & ART & 125 \\
\hline
\end{tabular}

ART, antiretroviral therapy.

months, although the rectum still showed less reduction in HIV DNA. ${ }^{121}$ In ART-suppressed patients, HIV DNA levels per million $\mathrm{CD}^{+}{ }^{+} \mathrm{T}$ cells were on average five to six times higher in the gut than blood, ${ }^{122,123}$ and levels of HIV DNA and unspliced HIV RNA per million $\mathrm{CD}^{+}{ }^{+} \mathrm{T}$ cells were higher in four different gut sites than in blood. ${ }^{124}$ One study calculated that the gut contains twice as many HIV DNA ${ }^{+}$ cells as blood, ${ }^{125}$ while another estimated that the gut contains $1.2 \times 10^{9}$ infected $\mathrm{CD}^{+} \mathrm{T}$ cells, or up to $95 \%$ of all HIV-infected cells in the body ${ }^{124}$ (Table 2). Based on the responses to ART intensification with one to two new antivirals, a follow-up study suggested that the ileum, but not other gut sites or blood, might be a site of ongoing replication in some patients on ART. ${ }^{40}$ In SIV-infected, ART-suppressed monkeys, SIV envelope protein was detected in the small bowel and colon, as well as other tissues, using a wholebody antibody-targeted positron emission tomography (ImmunoPET) with ${ }^{64} \mathrm{Cu}$-labeled SIV Gp120-specific antibody. ${ }^{126}$ When multiple tissues were analyzed in ARTsuppressed SIV-infected macaques, the gut had the highest levels of multiply spliced SIV RNA and the highest ratio of multiply spliced to unspliced SIV RNA. ${ }^{127}$

Despite these differences between gut and blood, it is unclear to what degree viral variants or infected cells traffic between the gut and blood. Some studies have reported HIV sequence compartmentalization between gut and blood. In ART-treated patients, phylogenetic trees and resistance profiles of HIV-1 protease and reverse transcriptase showed differences in HIV strains between blood and rectal mucosa. ${ }^{128}$ In chronically infected subjects not on therapy, primary $n e f$ quasispecies from paired plasma and sigmoid colon biopsies also showed compartmentalization. ${ }^{129}$ In addition, phylogenetic analysis of the Nef protein-encoding region in untreated patients also revealed compartmentalization of viral replication in various parts of the gut. ${ }^{130}$ However, phylogenetic analysis of HIV env DNA has also suggested crossinfection among resting and activated $\mathrm{CD}^{+} \mathrm{T}$ cells from blood and gut in patients on ART, ${ }^{122,131}$ although variants in the rectum were more heterogeneous than variants in the blood from untreated patients. ${ }^{131}$ Furthermore, when phylogenetic analysis was performed on colon, ileum, and blood samples from chronically infected individuals, no evidence of compartmentalization was found. ${ }^{132}$ These studies suggest that, while compartmentalization may be difficult to detect during untreated infection, long-term ART can influence HIV sequence compartmentalization in various tissues and regions of gut, but more studies are needed to understand how exactly this occurs.

In addition to tissue-specific differences in the nature of $\mathrm{HIV}$-infected cell types, the mechanisms of transcriptional control may differ between gut and blood. For example, the median ratio of HIV RNA to HIV DNA (average level of transcription per provirus) in the ileum was higher compared with the blood, suggesting that this gut site has a greater ratio of productive to latent infection. However, at all other gut sites, the median HIV RNA/DNA ratio was actually lower than that in the blood, suggesting that gut sites other than ileum have more "latently" infected cells. ${ }^{124}$ Since most gut lymphocytes display markers of T-cell activation, "latent", infection of these cells may differ from the classic latent infection in the blood, which was originally described in resting $\mathrm{CD}^{+} \mathrm{T}$ cells. Indeed, since T-cell activation typically drives HIV transcription, it is surprising that gut cells have such low levels of HIV transcription, suggesting that they are hyporesponsive to activating stimuli, or that activation markers have different meanings in the gut and blood. Furthermore, while T-cell activation correlated positively with HIV DNA levels in the blood, it correlated negatively with HIV DNA in the gut. ${ }^{124}$ The paradoxically low levels of transcription in the gut and the opposite correlations with Tcell activation in the gut and the blood suggest that activation has different consequences, or that HIV transcription is governed by different mechanisms, in the gut and blood.

It is unclear what mechanisms suppress HIV transcription in the immunologically active environment of the gut. Since most gut $\mathrm{CD}^{+} \mathrm{T}$ cells display markers of activation, it is difficult to invoke a lack of HIV transcriptional initiation due to paucity of host cell initiation factors associated with the resting state. Despite displaying a more active phenotype, likely due to exposure to gut microbial antigens, gut $\mathrm{CD} 4^{+} \mathrm{T}$ cells may be in a hyporesponsive or anergic state, perhaps as a means to maintain tolerance to normal flora. Future studies should investigate whether this tolerance or anergy could be mediated by epigenetic modification, negative $\mathrm{T}$-cell regulators (PD-1 and CTLA-4), $\mathrm{T}_{\text {reg }}$ cells, or other mechanisms, and how gut $\mathrm{CD}^{+} \mathrm{T}$ cells may differ from peripheral $\mathrm{CD} 4^{+}$ $\mathrm{T}$ cells in expression of cellular genes that influence HIV transcription and latency. 


\section{Immune Cell Targets in the Gut and the Path Toward HIV Cure}

The gut differs from peripheral blood in the types and frequencies of $\mathrm{HIV}$-infected $\mathrm{T}$-cell subsets. For example, while $\mathrm{T}_{\mathrm{CM}}$ and $\mathrm{T}_{\mathrm{TM}}$ cells contain the largest proportion of HIV DNA in the blood, ${ }^{36}$ in both ileum and rectum, effector memory $\mathrm{CD}^{+} \mathrm{T}$ cells harbor the largest proportion of HIV DNA and RNA, and HIV DNA was also detected in leukocytes other than $\mathrm{CD}^{+}{ }^{\mathrm{T}}$ cells. ${ }^{59}$ In the following sections, we explore several major immune cell targets that could contribute to HIV persistence in the gut, and we discuss their fate and key roles in HIV pathogenesis.

\section{Macrophages/monocytes}

Myeloid cells are the first line of defense in the gut, as they present antigens and support tissue repair. The expression of CCR5 varies greatly among gut macrophages, correlating with the position within the GI tract. Macrophages within the rectum, which are more likely to be in contact with HIV during rectal viral transmission, express much higher levels of CCR5 than those in proximal regions of the GI tract. ${ }^{133}$ Nonetheless, there is no consensus as to whether macrophages might serve as real reservoirs of latent, replication-competent HIV. ${ }^{134}$ Most of the controversy stems from the fact that macrophages act as phagocytic scavengers and although HIV DNA, HIV RNA, and protein can be detected in macrophages, it might come from phagocytosis of infected $\mathrm{CD}^{+}{ }^{\mathrm{T}}$ cells, ${ }^{135,136}$ as was documented for SIV. ${ }^{137}$ Evidence exists both for ${ }^{138,139}$ and against $^{79,140,141}$ infection of gut macrophages in ARTsuppressed patients. While $\mathrm{CD}^{+} \mathrm{T}$ cells harbor most HIV DNA and RNA in the gut, myeloid cells account for $4 \%$ of the total HIV DNA. ${ }^{142,143}$

Among myeloid cells, monocytes contain HIV variants that are different than those in $\mathrm{CD}^{+} \mathrm{T}$ cells and are genetically closely associated with variants present in long-term recipients of ART. ${ }^{144}$ In line with these findings, transmitted/ founder viruses have minimal tropism for macrophages, suggesting that macrophage infection occurs at a later stage after viral transmission. ${ }^{145}$ However, macrophages can sustain HIV replication in the absence of $\mathrm{T}$ cells in humanized myeloidonly mice, ${ }^{146}$ and HIV can persist in tissue macrophages even after ART treatment. ${ }^{147}$ Therefore, additional research is needed to unravel the contribution of tissue-specific macrophages to the total HIV reservoir in individuals on ART.

\section{Regulatory $T$ cells $\left(T_{\text {reg }}\right)$}

The impact of $\mathrm{T}_{\text {reg }}$ cells on HIV infection and their contribution to the HIV reservoir in vivo are subjects of debate, and evidence suggests that $\mathrm{T}_{\text {reg }}$ cells may play a dual role in HIV pathogenesis. ${ }^{148}$ Some studies support the beneficial impact exerted by $\mathrm{T}_{\text {reg }}$ cells in limiting autoimmunity, HIV replication, and $\mathrm{CD}^{+}$T-cell depletion, ${ }^{149-152}$ while others argue that they contribute to disease progression and dampened HIV-specific immune responses. ${ }^{153-156}$ While acutely SIV-infected macaques experience a rapid depletion of $\mathrm{T}_{\text {reg }}$ cells in gut lymphoid tissue, ${ }^{157}$ and $\mathrm{IL}_{17}{ }^{+} \mathrm{T}_{\text {regs }}$ derived from naive $T_{\text {reg }}$ are selectively reduced in virologically suppressed individuals, ${ }^{158}$ numerous studies concur that elevated $\mathrm{T}_{\text {reg }}$ frequencies are observed in both peripheral blood and the gut in ART-treated and ART-untreated HIV-infected individuals, ${ }^{148}$ particularly relative to $\mathrm{T}_{\mathrm{H}} 17$ and $\mathrm{T}_{\mathrm{H}} 22$ cells. Increased $\mathrm{T}_{\text {reg }}$ frequencies may be related to the general inflammation and tissue damage in the gut and peripheral tissues of both ART-naive and ART-treated patients.

$\mathrm{T}_{\text {reg }}$ cells are susceptible to HIV infection both in vitro ${ }^{159}$ and in vivo. ${ }^{157,160}$ Circulating $\mathrm{T}_{\text {reg }}$ cells express CCR5 levels similar to bulk $\mathrm{CD}^{+} \mathrm{T}$ cells. ${ }^{161}$ They appear to be more susceptible to R5-tropic than X4-tropic HIV-1 infection in vitro, but are not preferentially infected by HIV, compared with effector T cells in vivo. ${ }^{159}$ The burden of HIV DNA harbored by $\mathrm{T}_{\text {reg }}$ cells is disputed since some studies reported comparatively higher HIV DNA in $\mathrm{T}_{\text {reg }}$ relative to non- $\mathrm{T}_{\text {reg }} \mathrm{CD}^{+}$ cells, ${ }^{162-164}$ while others observed lower levels. ${ }^{165}$ Whether $\mathrm{T}_{\text {reg }}$ cells constitute a reservoir of HIV that harbors inducible and replication-competent virus in the gut is unknown, and more direct evidence is required.

\section{IL-17-producing helper $T$ cells $\left(T_{H} 17\right)$}

$\mathrm{T}_{\mathrm{H}} 17$ cells are characterized by the production of IL-17A, IL-17F, and IL-22. ${ }^{166} \mathrm{~T}_{\mathrm{H}} 17$ can alternatively be distinguished phenotypically by their expression of CCR6, ${ }^{167,168}$ which regulates cell migration into various anatomic sites, including the intestinal mucosa. ${ }^{169,170} \mathrm{~T}_{\mathrm{H}} 17$ cells play a critical role in defense and homeostasis, acting to safeguard mucosal integrity by inducing the proliferation of enterocytes, producing antibacterial defensins, and recruiting neutrophils in response to fungal or bacterial infection. ${ }^{166}$

$\mathrm{T}_{\mathrm{H}} 17$ cells harbor high levels of HIV DNA in vivo in ARTnaive HIV-infected individuals. ${ }^{171}$ In particular, peripheral $\mathrm{CCR}^{+} \mathrm{T}_{\mathrm{H}} 17$, along with $\mathrm{T}_{\mathrm{H}} 1-/ \mathrm{T}_{\mathrm{H}} 17$-polarized cells, contribute disproportionately to the pool of $\mathrm{CD}^{+}{ }^{\mathrm{T}}$ cells that harbor HIV DNA, and CCR6 potentially acts as a marker for blood and gut $\mathrm{CD}^{+} \mathrm{T}$ cells that are enriched for HIV DNA. ${ }^{172,173}$ Furthermore, the reported enrichment of HIV DNA and a lower ratio of cell-associated unspliced HIV RNA to DNA ratio in $\mathrm{CXCR}^{+}{ }^{+} \mathrm{CCR}^{+}$cells, including $\mathrm{T}_{\mathrm{H}} 17$ cells, are consistent with transcriptional silencing. ${ }^{173}$ Collectively, these data allude to the potential of $\mathrm{T}_{\mathrm{H}} 17$ to harbor latent HIV.

$\mathrm{T}_{\mathrm{H}} 17$ cells may also undergo self-renewal or homeostatic proliferation and retain a stem cell-like molecular signature, ${ }^{174,175}$ a combination of attributes that could make $\mathrm{T}_{\mathrm{H}} 17$ cells a long-lived, persistent reservoir in vivo. ${ }^{172,173,176,177}$ However, these studies did not directly assess replication competence of virus harbored by $\mathrm{T}_{\mathrm{H}} 17$ cells. Few studies have examined the contribution of $\mathrm{T}_{\mathrm{H}} 17$ cells to the HIV reservoir in the gut. The sigmoid HIV reservoir remains high despite long-term suppressive therapy, and HIV DNA levels in the sigmoid correlate negatively with sigmoid $\mathrm{T}_{\mathrm{H}} 17$ frequency, ${ }^{178}$ in line with previous work demonstrating a similar observation in peripheral blood. ${ }^{179}$ More direct evidence is required to determine if gut $\mathrm{T}_{\mathrm{H}} 17$ cells harbor significant levels of latent HIV, but current data suggest that $\mathrm{T}_{\mathrm{H}} 17$ cells are an important HIV reservoir in the gut.

\section{IFN- $\gamma$ - and IL-17-producing helper $T$ cells $\left(T_{H} 1 / T_{H} 17\right)$}

$\mathrm{CD}^{+} \mathrm{T}$ cells producing IL-17 and IFN- $\gamma$, termed $\mathrm{T}_{\mathrm{H}} 1 / \mathrm{T}_{\mathrm{H}} 17$, are particularly susceptible to HIV infection ${ }^{171}$ and appear to exhibit lower levels of antiviral factors and a higher state of cellular activation, ${ }^{180}$ which may contribute to their increased permissiveness to HIV infection. Despite the reduced frequency of $\mathrm{T}_{\mathrm{H}} 1 / \mathrm{T}_{\mathrm{H}} 17$ cells in ART-treated HIV-infected 
individuals relative to uninfected individuals, $\mathrm{T}_{\mathrm{H}} 1 / \mathrm{T}_{\mathrm{H}} 17$ and $\mathrm{T}_{\mathrm{H}} 17$ cells contribute significantly to the pool of integrated HIV DNA in peripheral blood. ${ }^{172}$ These data are in line with previous work indicating that integrated HIV persists in $\mathrm{T}_{\mathrm{H}} 1 / \mathrm{T}_{\mathrm{H}} 17$, defined by a CXCR $3^{+} \mathrm{CCR}^{+}$phenotype, ${ }^{173,176}$ and support the in vitro model of latency in which the CCR6-CCL20 axis plays a critical role in latency establishment. ${ }^{181}$ Notably, the frequency of CCR $6^{+}$memory $\mathrm{T}$ cells is higher in the colon than peripheral blood in ARTtreated individuals. ${ }^{172}$ Although the inducibility and replication competence of integrated HIV DNA recovered from $\mathrm{T}_{\mathrm{H}} 1 / \mathrm{T}_{\mathrm{H}} 17$ remain to be investigated, this subset likely constitutes an important reservoir for latent HIV in the gut.

\section{IL-22-producing helper $T$ cells $\left(T_{H} 22\right)$}

$\mathrm{CD} 4^{+} \mathrm{T}_{\mathrm{H}} 22$ cells are distinguished by their production of IL-22 and their expression of the chemokine receptors CCR6, CCR4, and CCR10, and the gut microbial sensor aryl hydrocarbon, which is a ligand-activated transcription factor. ${ }^{182}$ In concert with $\mathrm{T}_{\mathrm{H}} 17, \mathrm{~T}_{\mathrm{H}} 22$ promotes epithelial barrier integrity and mucosal healing through epithelial proliferation and increased production of mucus. ${ }^{183}$ In healthy HIVuninfected individuals, as well as in SIV-uninfected RM, the levels of $\mathrm{T}_{\mathrm{H}} 22$ cells in the gut are comparatively lower than $\mathrm{T}_{\mathrm{H}} 17$ cells, with the majority of IL-22-producing cells also producing IL-17. ${ }^{184,185}$ The imbalance of $\mathrm{T}_{\mathrm{H}} 22$ and $\mathrm{T}_{\text {reg }}$ cells triggered by HIV infection in the peripheral blood potentially contributes to subsequent loss of mucosal immunity and thus systemic immune activation, ${ }^{98}$ since the ablation of $\mathrm{T}_{\mathrm{H}} 22$ cells is only partially rescued with suppressive ART. ${ }^{98,186}$ Administration of IL-21 in combination with ART has been shown to improve $\mathrm{T}_{\mathrm{H}} 22$ reconstitution, reduce immune activation, and reduce the frequency of $\mathrm{CD}^{+} \mathrm{T}$ cells harboring replication-competent virus in lymph nodes from SIVinfected RM. ${ }^{187}$ ART treatment of SIV-infected RM also correlates with increased $\mathrm{T}_{\mathrm{H}} 22$ cell function and decreased SIV DNA content. ${ }^{186}$ However, the extent to which $\mathrm{T}_{\mathrm{H}} 22$ cells contribute to the pool of $\mathrm{CD}^{+} \mathrm{T}$ cells harboring replication-competent virus is undetermined. Although $\mathrm{T}_{\mathrm{H}} 22$ cells account for a relatively small proportion of $\mathrm{CD}^{+} \mathrm{T}$ cells in the gut and no studies have examined the levels of replication-competent HIV that they may harbor, the integral role of $\mathrm{T}_{\mathrm{H}} 22$ cells in maintaining epithelial barrier integrity in the gut suggests that future studies should investigate the contribution of these cells to the gut HIV reservoir.

\section{Follicular helper $T$ cells $\left(T_{F H}\right)$}

Within GC located in lymphoid follicles of secondary lymphoid organs, critical interactions between resident $\mathrm{B}$ cells and $\mathrm{T}_{\mathrm{FH}}$ cells promote high-affinity $\mathrm{T}$-dependent antibody responses, somatic hypermutation, and antibody class switching. ${ }^{188,189} \mathrm{GC}_{\mathrm{FH}}$ are primarily distinguished by their high expression of Bcl-6, a transcriptional regulator, ${ }_{190,191}$ and expression of CXCR5, a follicular homing receptor, ${ }^{192,193}$ as well as CXCR4, CD95, CD154, BTL, inducible T-cell costimulator (ICOS), CD40L, and PD-1, which are neither exclusive to $\mathrm{T}_{\mathrm{FH}}{ }^{188,189,194}$ nor uniformly expressed on all $\mathrm{T}_{\mathrm{FH}}$ cells. ${ }^{192,193,195}$ Human $\mathrm{T}_{\mathrm{FH}}$ cells express an RNA expression profile distinct from $\mathrm{T}_{\mathrm{H}} 1, \mathrm{~T}_{\mathrm{H}} 2$, and $\mathrm{T}_{\mathrm{H}} 17$ cells, ${ }^{190,196}$ and this profile can be markedly altered by HIV/SIV infection. ${ }^{197-199}$ This $\mathrm{CD}^{+}{ }^{+} \mathrm{T}$-cell subset serves as a major reservoir for HIV.
$\mathrm{T}_{\mathrm{FH}}$ cells are highly permissive to HIV and SIV ${ }^{195,197,199-202}$ and expand in lymphoid tissue during acute and chronic infection, ${ }^{199,203-205}$ although suppression of viremia by ART can attenuate $\mathrm{T}_{\mathrm{FH}}$ cell expansion. ${ }^{200,203}$ Concomitant with this expansion is an enrichment of HIV-/SIV-infected $\mathrm{T}_{\mathrm{FH}}$ cells in the lymph nodes. ${ }^{200,204,206}$ In contrast, SIV-infected RM experience an early and profound loss of splenic $\mathrm{T}_{\mathrm{FH}}$ cells, ${ }^{207}$ suggesting that HIV/SIV infection has diverging effects on $\mathrm{T}_{\mathrm{FH}}$ dynamics in various tissues.

$\mathrm{T}_{\mathrm{FH}}$ cells support high levels of HIV infection, replication, and virus production in vitro ${ }^{200}$ and in ART-naive patients, $\mathrm{T}_{\mathrm{FH}}$ cells exhibit the highest levels of HIV DNA in lymph nodes. ${ }^{200}$ A newly identified population of mucosal $\mathrm{T}_{\mathrm{FH}}$ cells isolated from the jejunum of RM harbors 10-fold higher levels of SIV gag DNA per cell than bulk $\mathrm{CD}^{+}$memory cells, ${ }^{208}$ underscoring the importance of $\mathrm{T}_{\mathrm{FH}}$ cells in the gut during HIV/SIV infection. It is unclear whether anatomic barriers facilitate HIV persistence in $\mathrm{GC}_{\mathrm{FH}}$ cells. Since the majority of $\mathrm{CD}^{+}$cytotoxic $\mathrm{T}$ cells lack the chemokine receptors required for migration into B-cell follicles in lymphoid tissue, ${ }^{206}$ these follicles may serve as a site of "immune privilege" in which HIV-infected $\mathrm{T}_{\mathrm{FH}}$ cells are not recognized and killed. However, the exclusion of $\mathrm{CD} 8^{+} \mathrm{T}$ cells from follicles may not be absolute, as several reports have described populations of $\mathrm{CD}^{+} \mathrm{T}$ cells capable of infiltrating B-cell follicles in rhesus lymph nodes ${ }^{209}$ and eradicating virus-infected $\mathrm{T}_{\mathrm{FH}}$ cells in a mouse model of LCMV infection, ${ }^{210,211}$ supporting an earlier discovery of $\mathrm{CCR}^{+} \mathrm{CCR}^{-}$cytotoxic $\mathrm{T}$ cells in B-cell follicles in human tonsillar tissue. ${ }^{212}$ The difficulty in identifying these populations may be ascribed to phenotypic and transcriptional differences that distinguish them from other $\mathrm{CD}^{+} \mathrm{T}$ cells. ${ }^{211}$ Nonetheless, the importance of cytotoxic T cells capable of infiltrating B-cell follicles is underscored by recent work demonstrating that engineered $\mathrm{CD}^{+} \mathrm{T}$ cells expressing human CXCR5 were shown to localize to B-cell follicles in vitro, ${ }^{213}$ alluding to the possibility of a new pathway to suppress persistent viral replication in $\mathrm{T}_{\mathrm{FH}}$ within these tissue sanctuaries.

In HIV-infected individuals on suppressive ART, lymph node PD- ${ }^{+} \mathrm{T}_{\mathrm{FH}}$ cells constitute the major cell type that can be induced to produce replication-competent virus, ${ }^{200}$ although the contribution of these cells to the infectious reservoir progressively decreases with time on ART. ${ }^{214} \mathrm{PD}$ 1 , a marker for T-cell exhaustion and homeostatic or antigeninduced proliferation, acts as a putative marker for memory in $\mathrm{GC} \mathrm{T}_{\mathrm{FH}} \cdot{ }^{66} \mathrm{PD}-1$ is one of three immune checkpoint molecules recently implicated in HIV persistence during ART, ${ }^{215}$ and its expression can result in $\mathrm{T}_{\mathrm{FH}}$ dysfunction after interaction with PD-L1 expressed on GC B cells. ${ }^{216}$ Furthermore, a strong association exists between PD-1 and the immune activation marker Ki-67 in circulating $\mathrm{CD}^{+} \mathrm{T}$ cells from ART-treated individuals, ${ }^{36,217}$ suggesting that homeostatic proliferation is a major mechanism that maintains the HIV reservoir in these cells. However, there is little agreement on expression levels of $\mathrm{Ki}-67$ in $\mathrm{T}_{\mathrm{FH}}$ cells from HIV-infected individuals; ${ }^{200,202}$ so it is unclear to what extent homeostatic proliferation contributes to HIV persistence in $\mathrm{T}_{\mathrm{FH}}$ cells.

Despite perturbation of $\mathrm{T}_{\mathrm{FH}}$ cell counts in tissues, such as the lymph nodes and spleen, during HIV infection, recent evidence suggests that there are no differences in gut $\mathrm{GC}_{\mathrm{FH}}, \mathrm{B}$ cells, or $\operatorname{IgA}^{+} \mathrm{B}$ cells between virologically suppressed HIV-infected individuals and uninfected controls. ${ }^{218}$ Nonetheless, peripheral $\left(\mathrm{pT}_{\mathrm{FH}}\right)$ cells are highly susceptible 
to HIV infection, particularly if they express PD-1, and virus reactivation can be observed following ex vivo stimulation. ${ }^{219}$ Although this observation has yet to be recapitulated in $\mathrm{T}_{\mathrm{FH}}$ cells from the gut, it suggests that $\mathrm{T}_{\mathrm{FH}}$ cells contribute to HIV latency in vivo. Further evidence supporting the contribution of gut $\mathrm{T}_{\mathrm{FH}}$ cells to the HIV reservoir comes from humanized mouse models of HIV, which suggest that $\mathrm{T}_{\mathrm{FH}}$ cells rapidly accumulate in gut mucosal tissues and are most permissive to HIV infection. ${ }^{220}$ Finally, the ileum is particularly enriched with lymphoid follicles ${ }^{221,222}$ and exhibits higher average levels of HIV transcription relative to blood and other gut sites, ${ }^{124}$ suggesting the ileum may be a site for HIV persistence in $\mathrm{T}_{\mathrm{FH}}$ cells. Together, these data underscore the importance of this $\mathrm{CD}^{+}{ }^{+} \mathrm{T}$-cell subset as a potential HIV reservoir in the gut.

\section{Transitional memory $T$ cells $\left(T_{T M}\right)$}

Peripheral $\mathrm{T}_{\mathrm{TM}}$, along with $\mathrm{T}_{\mathrm{CM}}$, are major cellular reservoirs for HIV DNA in circulating CD4 ${ }^{+} \mathrm{T}$ cells. ${ }^{36}$ Relative to $\mathrm{T}_{\mathrm{N}}, \mathrm{T}_{\mathrm{SCM}}$, and $\mathrm{T}_{\mathrm{CM}}, \mathrm{T}_{\mathrm{TM}}$ cells express higher levels of CCR5, which may contribute to their susceptibility to HIV infection. $^{223}$ Homeostatic proliferation driven by IL-7-induced mitosis of infected $\mathrm{T}_{\mathrm{TM}}$ may help maintain the size, genetic diversity, and persistence of the HIV reservoir in $\mathrm{T}_{\mathrm{TM}}{ }^{36}$ In individuals with low $\mathrm{CD}^{+}{ }^{+} \mathrm{T}$-cell counts, $\mathrm{T}_{\mathrm{TM}}$ account for a greater proportion of the HIV DNA, with additional contribution from $\mathrm{T}_{\mathrm{CM}}$ that differentiate into $\mathrm{T}_{\mathrm{TM}}$ cells. ${ }^{36}$ The finding that $\mathrm{T}_{\mathrm{TM}}$ likely harbor high levels of total or integrated proviral $\mathrm{DNA}^{36}$ is echoed by other studies in treatment-naive acutely infected individuals, ${ }^{224}$ ART-treated individuals, ${ }^{21,172,225-227}$ and long-term nonprogressors. ${ }^{228}$ Although one study questioned how much the resting $\mathrm{T}_{\mathrm{TM}}$ compartment contributes to the pool of cells harboring infectious proviruses, ${ }^{229}$ another showed inducible, replicationcompetent HIV in $\mathrm{T}_{\mathrm{TM}}$ of posttreatment HIV controllers and implicated this population as the main contributor to the HIV-1 reservoir. ${ }^{22}$ In addition, $\mathrm{HIV}$ is more robustly reactivated in the $\mathrm{T}_{\mathrm{TM}} / \mathrm{T}_{\mathrm{EM}}$ subsets than $\mathrm{T}_{\mathrm{CM}}$ by a retinoid, all-trans retinoic acid, ${ }^{172}$ and NF-kB inducers (e.g., PMA + ionomycin, antiCD3 + anti-CD28 antibodies, and prostratin) preferentially reactivate $\mathrm{HIV}$ provirus from latently infected $\mathrm{T}_{\mathrm{TM}}$ in vitro. ${ }^{230}$ Moreover, PD-1 is highly expressed in $\mathrm{T}_{\mathrm{TM}}$ during both acute and chronic HIV-1 infection and does not normalize to levels seen in uninfected individuals, despite prolonged ART treatment. ${ }^{231}$ Increased PD-1 expression also correlates with inducible virus, ${ }^{215}$ providing further evidence implicating $\mathrm{T}_{\mathrm{TM}}$ as an important HIV reservoir.

Little is known about the contribution of $\mathrm{T}_{\mathrm{TM}}$ to the HIV reservoir in the gut. Despite high levels of T-cell activation in the gut even during suppressive ART, ${ }^{113}$ a paradoxically low level of HIV transcription is observed. ${ }^{124} \mathrm{~T}_{\mathrm{TM}}$ account for a larger proportion of $\mathrm{CD}^{+} \mathrm{T}$ cells in the ileum and rectum relative to peripheral blood, ${ }^{59}$ and HIV DNA levels per $\mathrm{CD}^{+}$ $\mathrm{T}$ cell are higher in both gut sites than in blood. ${ }^{124}$ Furthermore, rectal $\mathrm{T}_{\mathrm{TM}}$ display lower average levels of HIV transcription per infected cell than peripheral blood $\mathrm{T}_{\mathrm{TM}},{ }^{59}$ alluding to existence of transcriptionally silent HIV harbored by gut $\mathrm{T}_{\mathrm{TM}}$. With these data, $\mathrm{T}_{\mathrm{TM}}$ likely play a considerable role in HIV persistence in the gut, although further research is required to evaluate the contribution of $\mathrm{T}_{\mathrm{TM}}$ as a cellular reservoir for latent HIV in the gut.

\section{Tissue-resident memory $T$ cells $\left(T_{R M}\right)$}

Most of the memory $\mathrm{T}$ cells found in mucosal tissues do not recirculate to the blood; instead, they are retained locally in specific tissue sites. Referred to as tissue-resident memory $\mathrm{T}\left(\mathrm{T}_{\mathrm{RM}}\right)$ cells, ${ }^{232,233}$ they can respond rapidly upon reexposure to cognate antigens. ${ }^{54,65}$ Thus, $\mathrm{T}_{\mathrm{RM}}$ cells are an effective first line of defense against invading pathogens in mucosal tissues. ${ }^{233,234}$ In general, less is known about $\mathrm{CD} 4^{+} \mathrm{T}_{\mathrm{RM}}$ cells and their functions than about $\mathrm{CD}^{+} \mathrm{T}_{\mathrm{RM}}$ cells. ${ }^{65}$ However, $\mathrm{CD} 4^{+}$ $\mathrm{T}_{\mathrm{RM}}$ cells have been identified in lung, skin, and mucosal surfaces, where they seem to direct protective responses and coordinate the recruitment of immune cells. ${ }^{65}$

Phenotypically, $\mathrm{CD} 4^{+} \mathrm{T}_{\mathrm{RM}}$ cells are distinguished from circulating $\mathrm{T}_{\mathrm{EM}}$ populations based on their surface expression of CD69. ${ }^{65,235}$ In humans, putative $\mathrm{T}_{\mathrm{RM}}$ cells in mucosal, lymphoid, and peripheral tissue sites are also identified by expression of CD69. ${ }^{56}$ More than $80 \%$ of the $\mathrm{CD}^{+} \mathrm{T}$ cells in colon, skin, and tonsil are $\mathrm{CD}^{+} 9^{+}$, whereas this population is mostly absent in blood. ${ }^{56,57,236}$ The lectin CD69 has traditionally been thought of as an early marker of T-cell activation, since it is transiently upregulated early after T-cell receptor stimulation or in response to proinflammatory cytokines, including type I IFNs (IFN- $\alpha$ and IFN- $\beta$ ) and tumor necrosis factor. CD69 contributes to T-cell retention in tissues by regulating sphingosine-1-phosphate receptor 1 , which controls the egress of lymphocytes from certain tissues. Interestingly, in both ileum and rectum, the largest proportion of HIV DNA and RNA is present in CD4 ${ }^{+} \mathrm{T}_{\mathrm{EM}}$ cells, ${ }^{59}$ and since $\mathrm{T}_{\mathrm{RM}}$ cells in the gut have phenotypes similar to $\mathrm{T}_{\mathrm{EM}}$ cells, ${ }^{56}$ the previously studied gut $\mathrm{T}_{\mathrm{EM}}$ reservoir may also encompass $\mathrm{T}_{\mathrm{RM}}$ cells.

$\mathrm{T}_{\mathrm{RM}}$ cells respond to inflammatory and tissue-specific environmental factors, which also determine their resident memory phenotype. For example, high expression of transforming growth factor-beta within the epithelium induces the expression of CD103 integrin on a subset of $\mathrm{T}_{\mathrm{RM}}$ cells. $^{237-239}$ CD103 allows T cells to interact with epithelial E-cadherin and to be retained in the epithelium. ${ }^{240}$ Compared to $\mathrm{CD}^{+} \mathrm{T}_{\mathrm{RM}}$ cells, a very small fraction of $\mathrm{CD} 4^{+} \mathrm{T}_{\mathrm{RM}}$ cells are positive for CD103. ${ }^{56,241}$ High frequencies of CD103 ${ }^{+} \mathrm{CD} 4^{+} \mathrm{T}_{\mathrm{RM}}$ cells in the colon, lung, and liver also express CCR $5,{ }^{56}$ indicating that these cells could be susceptible to HIV infection. While the exact contribution of $\mathrm{T}_{\mathrm{RM}}$ cells to the HIV reservoir in the gut or other tissues remains unknown, adipose tissue in ART-treated individuals contains HIV-1 DNA, and most of the CD4 ${ }^{+}$T cells in adipose tissue are $\mathrm{CD} 69^{+}$, suggesting that they belong to the $\mathrm{T}_{\mathrm{RM}}$ population. Coculturing of adipocytes from uninfected donors enhanced HIV infection of memory $\mathrm{CD}^{+} \mathrm{T}$ cells in a contact-independent manner, indicating that adipocytes promote HIV infection in memory $\mathrm{CD}^{+} \mathrm{T}$ cells by secretion of unknown soluble factors. ${ }^{242}$ In another study, $\mathrm{CD}^{+} \mathrm{T}$ cells with $\mathrm{T}_{\mathrm{RM}}$ phenotype $\left(\mathrm{CD} 45 \mathrm{RO}^{+} \mathrm{CD} 9^{+}\right)$in adipose tissues were found to harbor HIV DNA, and these cells produced HIV RNA upon in vitro reactivation with allogenic preactivated $\mathrm{CD}^{+} \mathrm{T}$ cells. ${ }^{243}$ Furthermore, CD $4^{+} \mathrm{CD} 69^{+} \mathrm{T}$ cells collected from female cervix were preferential targets for infection with a CCR5tropic pseudovirus in tissue culture. ${ }^{244}$ Therefore, $\mathrm{T}_{\mathrm{RM}}$ cells in the gut may also serve as a pool of latently infected cells. ${ }^{33,245}$

\section{Gamma-delta T cells}

HIV-1 may reside in nonconventional $\mathrm{T}$ cells, such as gamma-delta T cells ( $\gamma \delta$ T cells). The $\gamma \delta$ T cells are distinct 
from $\alpha \beta$ T cells, ${ }^{246}$ account for $0.5 \%-5 \%$ of adult murine or human $\mathrm{CD}^{+}$cells, ${ }^{247}$ are mainly $\mathrm{CD} 4^{-} \mathrm{CD} 8^{-248,249}$ and are more abundant in mucosal tissues than in peripheral blood or lymph nodes. ${ }^{247}$ There are two major subsets of $\gamma \delta$ T cells in humans, distinguished by the expression of $\mathrm{V} \delta 1$ or $\mathrm{V} \delta 2$ genes. ${ }^{250,251} \mathrm{~V} \delta 1 \mathrm{~T}$ cells respond to antigens from pathogenic bacteria, ${ }^{252,253}$ whereas stress-related chemical compounds activate $\mathrm{V} \delta 2$ cells. ${ }^{246,250,254}$ The $\gamma \delta$ T cells exert protective functions against a number of viral infections, including HIV ${ }^{255}$ although infection with HIV-1 persistently dysregulates subsets of circulating and mucosal $\gamma \delta \mathrm{T}$ cells. ${ }^{256}$ In healthy individuals, $\mathrm{V} \delta 1$ cells are less abundant than $\mathrm{V} \delta 2$ cells in blood, ${ }^{247}$ whereas in mucosal sites such as the GI tract and endocervical and vaginal tissues, $\mathrm{V} \delta 1 \mathrm{~T}$ cells predominate. $^{257}$

In mucosal tissues, the $\mathrm{V} \delta 1 \mathrm{~T}$ cells are also the most severely diminished subset in chronically HIV-infected patients. ${ }^{258-260}$ During ART, even in patients with $\mathrm{CD}^{+}{ }^{+}$T-cell reconstitution, $\gamma \delta \mathrm{T}$-cell frequency and function are not restored to normal levels. ${ }^{261} \mathrm{~A}$ fraction of both peripheral and mucosal $\gamma \delta$ T-cell populations expresses CD4, CCR5, and CXCR4. ${ }^{258,262-264}$ Peripheral V $\delta 2$ T cells express higher levels of CCR5 and can be infected with HIV-1 in vitro. ${ }^{265,266}$ Interestingly, peripheral $\mathrm{V} \delta 2$ cells from ART-treated patients harbor HIV-1 DNA in quantities that exceed those of resting $\mathrm{CD}^{+} \mathrm{T}$ cells, and the majority of these cells contain replication-competent virus. ${ }^{267}$ However, the exact contribution of $\gamma \delta$ T cells to the gut HIV reservoir remains unknown.

Other nonconventional T cells, such as NKT and MAIT cells, are also severely diminished in numbers or frequencies in HIV-infected humans. ${ }^{268-270}$ However, no evidence suggests that these nonconventional T cells serve as HIV reservoirs.

Although the following cell types are not typically found in the gut, they may still contribute to the gut reservoir upon activation, differentiation, and subsequent migration to the gut.

\section{Stem cell memory $T$ cells $\left(T_{S C M}\right)$}

$\mathrm{T}_{\mathrm{SCM}}$ cells are permissive to HIV-1 infection with both R5and X4-tropic viruses, ${ }^{223,271,272}$ which can yield latently infected $\mathrm{T}_{\mathrm{SCM}}$ at a similar propensity to other $\mathrm{CD}^{+} \mathrm{T}$-cell subsets. ${ }^{271}$ There is no consensus regarding the contribution of $\mathrm{T}_{\mathrm{SCM}}$ cells to the latent HIV reservoir in the gut. To date, the overwhelming majority of research has focused on $\mathrm{T}_{\mathrm{SCM}}$ in peripheral blood. In this regard, one study demonstrated that $\mathrm{T}_{\mathrm{SCM}}$ represent a very stable reservoir in vivo, and that a high frequency of HIV-1 provirus was detected in purified $\mathrm{T}_{\mathrm{SCM}}$ from virologically suppressed, HIV-infected individuals. ${ }^{273}$ This study reported that the per-cell levels of HIV-1 DNA were highest in the $\mathrm{CD} 4^{+} \mathrm{T}_{\mathrm{SCM}}$ cell subset (compared to $\mathrm{T}_{\mathrm{N}}, \mathrm{T}_{\mathrm{CM}}, \mathrm{T}_{\mathrm{EM}}$, and $\mathrm{T}_{\mathrm{TD}}$ ) irrespective of treatment. ${ }^{273}$ In contrast, another study observed that $\mathrm{T}_{\mathrm{SCM}}$ harbor the lowest level of integrated HIV-1 DNA in individuals on suppressive ART. ${ }^{274}$ These disparities may reflect differences in the study participants or the methods used to sort $\mathrm{T}_{\mathrm{SCM}}$ and measure viral DNA. Nonetheless, these studies agree that the contribution of $\mathrm{CD}^{+} \mathrm{T}_{\mathrm{SCM}}$ to the pool of infected cells may increase over time, concomitant with the decline of other $\mathrm{T}$ cell subsets in vivo. ${ }^{273,274}$

Although $\mathrm{T}_{\mathrm{SCM}}$ may represent an exceptionally stable and durable component of the HIV latent reservoir in peripheral $\mathrm{CD}^{+} \mathrm{T}$ cells, ${ }^{53,274} \mathrm{~T}_{\mathrm{SCM}}$ cells in NHP models are virtually absent from mucosal surfaces, including the jejunum and rectum. ${ }^{53}$ Furthermore, both $\mathrm{CD} 4^{+}$and $\mathrm{CD} 8^{+} \mathrm{T}_{\mathrm{SCM}}$ are more prevalent in the peripheral blood than in GALT from both healthy and untreated HIV-infected individuals. ${ }^{275}$ Additional studies are needed to investigate the contribution of $\mathrm{T}_{\mathrm{SCM}}$ cells to the gut HIV reservoir, but this contribution might be limited due to the low frequency of $\mathrm{T}_{\mathrm{SCM}}$ cells in the gut.

\section{Central memory $T$ cells $\left(T_{C M}\right)$}

$\mathrm{T}_{\mathrm{CM}}$ cells are long-lived cells that constitute a major cellular reservoir for HIV in peripheral blood. ${ }^{36,229,276}$ The $\mathrm{CD} 4^{+} \mathrm{T}_{\mathrm{CM}}$ subset harbors a high frequency of viral DNA in the blood, exhibiting $\sim 10$-fold greater levels of viral copies than terminally differentiated memory cells. ${ }^{82}$ Blood $\mathrm{T}_{\mathrm{CM}}$ cells are also enriched for cells infected with replicationcompetent virus. ${ }^{229}$ Numerous studies in mice and humans demonstrate that $\mathrm{T}_{\mathrm{FH}}$ cells develop into memory cells and are part of the $\mathrm{T}_{\mathrm{CM}}$ compartment. ${ }^{66}$ Recent findings suggest that $\mathrm{pT}_{\mathrm{FH}}$, defined by their expression of CXCR5, constitute a large proportion of circulating $\mathrm{T}_{\mathrm{CM}}$ cells and are highly susceptible to HIV infection. ${ }^{219}$ In ART-suppressed individuals, $\mathrm{pT}_{\mathrm{FH}}$ cells harbor inducible virus capable of reactivation upon ex vivo stimulation. ${ }^{219}$ Importantly, $20 \%$ of human $\mathrm{T}_{\mathrm{CM}} \mathrm{CD} 4^{+} \mathrm{T}$ cells are estimated to express CXCR5, suggesting that $\mathrm{T}_{\mathrm{FH}}$ make up a large proportion of the memory pool. ${ }^{66}$ However, memory $\mathrm{T}_{\mathrm{FH}}$ cells predominantly reside in the spleen, lymph nodes, and bone marrow. ${ }^{66}$ Relative to peripheral blood, the proportion of $\mathrm{T}_{\mathrm{CM}}$ cells as a percentage of all $\mathrm{CD}^{+}{ }^{+} \mathrm{T}$ cells is very low in the GI tract, where cells with a more differentiated phenotype, such as $\mathrm{T}_{\mathrm{TM}}, \mathrm{T}_{\mathrm{EM}}$, and $\mathrm{T}_{\mathrm{RM}}$, predominate. ${ }^{59,124}$ Thus, $\mathrm{T}_{\mathrm{CM}}$ are unlikely to contribute significantly to the reservoir of latent HIV in the gut.

\section{Conclusions and Future Perspectives}

On the path toward HIV cure, further studies are needed to understand the contribution of gut tissue and gut cell subsets to the HIV latent reservoir. Since mechanisms of HIV persistence may vary significantly depending on the cell type and tissue microenvironment, therapeutic strategies for HIV eradication will require identification of all cellular subsets and mechanisms that contribute to viral persistence in ARTtreated patients. Although studies on circulating $\mathrm{CD}^{+}{ }^{+} \mathrm{T}$ cells have provided valuable knowledge about the mechanisms of cell death and viral persistence that lead to immunodeficiency, tissue $\mathrm{CD}^{+}{ }^{+} \mathrm{T}$ cells have very different phenotypic and functional properties, and hence may involve significantly different mechanisms of HIV persistence. Moreover, the proportion of the body's $\mathrm{CD} 4^{+} \mathrm{T}$ cells in mucosal tissues is much higher than in the blood, which adds to the tremendous value of studying rare subsets of $\mathrm{CD}^{+} \mathrm{T}$ cells in various tissue compartments. In addition, virus production in the gut leads to breakdown of the mucosal barrier, microbial translocation, and local and systemic immune activation, which may further increase viral replication or reactivation from latency and contribute to the organ damage observed even in ART-treated patients. Arresting this vicious cycle of immune activation requires restoration of the gut mucosal barrier, which will require new therapies that can eliminate residual virus production from ongoing replication or latent reservoirs. Thus, understanding how the gut environment 
contributes to HIV persistence may be critical both for new therapies aimed at reducing HIV-associated immune activation and for strategies aimed at functional or complete HIV cure.

Although recent advances in cytometry and other molecular techniques have allowed deep phenotyping and molecular characterization of various immune cells from blood and mucosal tissues, technical challenges limit the ability to quantify viral DNA/RNA or replication-competent virus from rare subsets of $\mathrm{CD}^{+} \mathrm{T}$ cells from hard-to-obtain mucosal tissues. In addition, current enzymatic digestion protocols allow recovery of only a small fraction of immune cells from tissue biopsies. A comparison of cell numbers by immunohistochemistry and flow cytometry on human rectosigmoid biopsies suggested that only $\sim 20 \%$ of $\mathrm{T}$ cells can be recovered by enzymatic digestion procedures for downstream analyses. ${ }^{62}$ Therefore, improvements in methodologies for maximum cell recovery and viral detection would be helpful to determine rare cell types that contribute to HIV persistence.

The observation that proviral sequences do not significantly change in the HIV-1 reservoir during suppressive therapy ${ }^{277}$ raises hope that phenotypic identification of true latently infected cells in patients on long-term ART may greatly enhance innovation of strategies to selectively target these cells, which would be a major milestone toward HIV cure.

\section{Acknowledgments}

We thank Peter W. Hunt (UCSF) for critical reading of this article, and Gary Howard (Gladstone) for editorial assistance. S.S. is also supported by California HIV/AIDS Research Program IDEA Award (CHRP ID15-GI-059) and National Institutes of Health (NIH; DP2 AI112244). S.S. and S.Y. are supported as part of the amfAR Institute for HIV Cure Research, with funding from amfAR grant number 109301. S.Y. is also supported by the National Institutes of Health (1R01DK108349-01, U01AI034989). S.K. was supported by a CFAR Mentored Scientist Award (P30 AI027763).

\section{Author Disclosure Statement}

No competing financial interests exist.

\section{References}

1. Buzon MJ, Martin-Gayo E, Pereyra F, et al.: Long-term antiretroviral treatment initiated at primary HIV-1 infection affects the size, composition, and decay kinetics of the reservoir of HIV-1-infected CD4 T cells. J Virol 2014;88:10056-10065.

2. Besson GJ, Lalama CM, Bosch RJ, et al.: HIV-1 DNA decay dynamics in blood during more than a decade of suppressive antiretroviral therapy. Clin Infect Dis 2014;59: 1312-1321.

3. Wagner TA, McKernan JL, Tobin NH, Tapia KA, Mullins JI, Frenkel LM: An increasing proportion of monotypic HIV-1 DNA sequences during antiretroviral treatment suggests proliferation of HIV-infected cells. J Virol 2013;87: 1770-1778.

4. Finzi D, Hermankova M, Pierson T, et al:: Identification of a reservoir for HIV-1 in patients on highly active antiretroviral therapy. Science 1997;278:1295-1300.
5. Chun TW, Carruth L, Finzi D, et al.: Quantification of latent tissue reservoirs and total body viral load in HIV-1 infection. Nature 1997;387:183-188.

6. Chun TW, Finzi D, Margolick J, Chadwick K, Schwartz D, Siliciano RF: In vivo fate of HIV-1-infected T cells: Quantitative analysis of the transition to stable latency. Nat Med 1995;1:1284-1290.

7. Wong JK, Hezareh M, Gunthard HF, et al.: Recovery of replication-competent HIV despite prolonged suppression of plasma viremia. Science 1997;278:1291-1295.

8. Cary DC, Fujinaga K, Peterlin BM: Molecular mechanisms of HIV latency. J Clin Invest 2016;126:448-454.

9. Dahabieh MS, Battivelli E, Verdin E: Understanding HIV latency: The road to an HIV cure. Annu Rev Med 2015;66: 407-421.

10. Wiegand A, Spindler J, Hong FF, et al.: Single-cell analysis of HIV-1 transcriptional activity reveals expression of proviruses in expanded clones during ART. Proc Natl Acad Sci U S A 2017;114:E3659-E3668.

11. Kaiser P, Joshi SK, Kim P, et al.: Assays for precise quantification of total (including short) and elongated HIV-1 transcripts. J Virol Methods 2017;242:1-8.

12. Descours B, Petitjean G, Lopez-Zaragoza JL, et al.: CD32a is a marker of a CD4 T-cell HIV reservoir harbouring replication-competent proviruses. Nature 2017;543: 564-567.

13. Pillai SK, Deeks SG: Signature of the sleeper cell: A biomarker of HIV latency revealed. Trends Immunol 2017; 38:457-458.

14. Hunt PW, Sinclair E, Rodriguez B, et al:: Gut epithelial barrier dysfunction and innate immune activation predict mortality in treated HIV infection. J Infect Dis 2014;210: 1228-1238.

15. Somsouk M, Estes JD, Deleage C, et al.: Gut epithelial barrier and systemic inflammation during chronic HIV infection. AIDS 2015;29:43-51.

16. Brenchley JM, Price DA, Schacker TW, et al: : Microbial translocation is a cause of systemic immune activation in chronic HIV infection. Nat Med 2006;12:1365-1371.

17. Whitney JB, Hill AL, Sanisetty S, et al.: Rapid seeding of the viral reservoir prior to SIV viraemia in rhesus monkeys. Nature 2014;512:74-77.

18. Chavez L, Calvanese V, Verdin E: HIV latency is established directly and early in both resting and activated primary CD4 T Cells. PLoS Pathog 2015;11:e1004955.

19. Chun TW, Engel D, Berrey MM, Shea T, Corey L, Fauci AS: Early establishment of a pool of latently infected, resting CD4(+) $\mathrm{T}$ cells during primary HIV-1 infection. Proc Natl Acad Sci U S A 1998;95:8869-8873.

20. Luzuriaga $\mathrm{K}$, Gay $\mathrm{H}$, Ziemniak $\mathrm{C}$, et al.: Viremic relapse after HIV-1 remission in a perinatally infected child. $\mathrm{N}$ Engl J Med 2015;372:786-788.

21. Cheret A, Bacchus-Souffan C, Avettand-Fenoel V, et al: Combined ART started during acute HIV infection protects central memory $\mathrm{CD}^{+} \mathrm{T}$ cells and can induce remission. J Antimicrob Chemother 2015;70:2108-2120.

22. Saez-Cirion A, Bacchus C, Hocqueloux L, et al.: Posttreatment HIV-1 controllers with a long-term virological remission after the interruption of early initiated antiretroviral therapy ANRS VISCONTI Study. PLoS Pathog 2013;9:e1003211.

23. Rouzine IM, Weinberger AD, Weinberger LS: An evolutionary role for HIV latency in enhancing viral transmission. Cell 2015;160:1002-1012. 
24. Marsili G, Remoli AL, Sgarbanti M, Perrotti E, Fragale A, Battistini A: HIV-1, interferon and the interferon regulatory factor system: An interplay between induction, antiviral responses and viral evasion. Cytokine Growth Factor Rev 2012;23:255-270.

25. Solis M, Nakhaei P, Jalalirad M, et al.: RIG-I-mediated antiviral signaling is inhibited in HIV-1 infection by a protease-mediated sequestration of RIG-I. J Virol 2011;85: 1224-1236.

26. Iyer SS, Bibollet-Ruche F, Sherrill-Mix S, et al:: Resistance to type 1 interferons is a major determinant of HIV-1 transmission fitness. Proc Natl Acad Sci U S A 2017;114: E590-E599.

27. Ranganath N, Sandstrom TS, Fadel S, Cote SC, Angel JB: Type I interferon responses are impaired in latently HIV infected cells. Retrovirology 2016;13:66.

28. Finzi D, Blankson J, Siliciano JD, et al.: Latent infection of $\mathrm{CD}^{+} \mathrm{T}$ cells provides a mechanism for lifelong persistence of HIV-1, even in patients on effective combination therapy. Nat Med 1999;5:512-517.

29. Ramratnam B, Mittler JE, Zhang L, et al.: The decay of the latent reservoir of replication-competent HIV-1 is inversely correlated with the extent of residual viral replication during prolonged anti-retroviral therapy. Nat Med 2000;6:82-85.

30. Siliciano JD, Kajdas J, Finzi D, et al: : Long-term followup studies confirm the stability of the latent reservoir for HIV-1 in resting CD4 ${ }^{+} \mathrm{T}$ cells. Nat Med 2003;9:727-728.

31. Strain MC, Gunthard HF, Havlir DV, et al.: Heterogeneous clearance rates of long-lived lymphocytes infected with HIV: Intrinsic stability predicts lifelong persistence. Proc Natl Acad Sci U S A 2003;100:4819-4824.

32. Zhang L, Ramratnam B, Tenner-Racz K, et al:: Quantifying residual HIV-1 replication in patients receiving combination antiretroviral therapy. N Engl J Med 1999;340: $1605-1613$.

33. Murray AJ, Kwon KJ, Farber DL, Siliciano RF: The latent reservoir for HIV-1: How immunologic memory and clonal expansion contribute to HIV-1 persistence. J Immunol 2016;197:407-417.

34. Hosmane NN, Kwon KJ, Bruner KM, et al:: Proliferation of latently infected $\mathrm{CD}^{+} \mathrm{T}$ cells carrying replicationcompetent HIV-1: Potential role in latent reservoir dynamics. J Exp Med 2017;214:959-972.

35. Josefsson L, von Stockenstrom S, Faria NR, et al.: The HIV-1 reservoir in eight patients on long-term suppressive antiretroviral therapy is stable with few genetic changes over time. Proc Natl Acad Sci U S A 2013;110:E4987E4996.

36. Chomont N, El-Far M, Ancuta P, et al.: HIV reservoir size and persistence are driven by $\mathrm{T}$ cell survival and homeostatic proliferation. Nat Med 2009;15:893-900.

37. Maldarelli F, Wu X, Su L, et al.: HIV latency. Specific HIV integration sites are linked to clonal expansion and persistence of infected cells. Science 2014;345:179-183.

38. Fletcher CV, Staskus K, Wietgrefe SW, et al.: Persistent HIV-1 replication is associated with lower antiretroviral drug concentrations in lymphatic tissues. Proc Natl Acad Sci U S A 2014;111:2307-2312.

39. Lorenzo-Redondo R, Fryer HR, Bedford T, et al.: Persistent HIV-1 replication maintains the tissue reservoir during therapy. Nature 2016;530:51-56.

40. Yukl SA, Shergill AK, McQuaid K, et al:: Effect of raltegravir-containing intensification on HIV burden and
T-cell activation in multiple gut sites of HIV-positive adults on suppressive antiretroviral therapy. AIDS 2010;24: 2451-2460.

41. Bingham R, Ahmed N, Rangi P, Johnson M, Tyrer M, Green J: HIV encephalitis despite suppressed viraemia: A case of compartmentalized viral escape. Int J STD AIDS 2011;22:608-609.

42. Peluso MJ, Ferretti F, Peterson J, et al.: Cerebrospinal fluid HIV escape associated with progressive neurologic dysfunction in patients on antiretroviral therapy with well controlled plasma viral load. AIDS 2012;26: 1765-1774.

43. Eisele E, Siliciano RF: Redefining the viral reservoirs that prevent HIV-1 eradication. Immunity 2012;37:377-388.

44. Cossarizza A, Ortolani C, Paganelli R, et al.: CD45 isoforms expression on $\mathrm{CD}^{+}$and $\mathrm{CD}^{+} \mathrm{T}$ cells throughout life, from newborns to centenarians: Implications for $\mathrm{T}$ cell memory. Mech Ageing Dev 1996;86:173-195.

45. Saule P, Trauet J, Dutriez V, Lekeux V, Dessaint JP, Labalette M: Accumulation of memory $\mathrm{T}$ cells from childhood to old age: Central and effector memory cells in CD4(+) versus effector memory and terminally differentiated memory cells in CD8(+) compartment. Mech Ageing Dev 2006;127:274-281.

46. Thome JJ, Yudanin N, Ohmura Y, et al.: Spatial map of human $\mathrm{T}$ cell compartmentalization and maintenance over decades of life. Cell 2014;159:814-828.

47. Fritsch RD, Shen X, Sims GP, Hathcock KS, Hodes RJ, Lipsky PE: Stepwise differentiation of CD4 memory T cells defined by expression of CCR7 and CD27. J Immunol 2005;175:6489-6497.

48. Okada R, Kondo T, Matsuki F, Takata H, Takiguchi M: Phenotypic classification of human $\mathrm{CD}^{+}{ }^{+} \mathrm{T}$ cell subsets and their differentiation. Int Immunol 2008;20:1189-1199.

49. Cartwright EK, Palesch D, Mavigner M, Paiardini M, Chahroudi A, Silvestri G: Initiation of antiretroviral therapy restores $\mathrm{CD} 4^{+} \mathrm{T}$ memory stem cell homeostasis in simian immunodeficiency virus-infected macaques. J Virol 2016;90:6699-6708.

50. Flynn JK, Gorry PR: Stem memory T cells (TSCM)-their role in cancer and HIV immunotherapies. Clin Transl Immunology 2014;3:e20.

51. Lugli E, Gattinoni L, Roberto A, et al.: Identification, isolation and in vitro expansion of human and nonhuman primate T stem cell memory cells. Nat Protoc 2013;8:33-42.

52. Gattinoni L, Lugli E, Ji Y, et al.: A human memory T cell subset with stem cell-like properties. Nat Med 2011;17: 1290-1297.

53. Lugli E, Dominguez MH, Gattinoni L, et al.: Superior $\mathrm{T}$ memory stem cell persistence supports long-lived T cell memory. J Clin Invest 2013;123:594-599.

54. Beura LK, Masopust D: SnapShot: Resident memory T cells. Cell 2014;157:1488. e1.

55. Turner DL, Gordon CL, Farber DL: Tissue-resident T cells, in situ immunity and transplantation. Immunol Rev 2014; 258:150-166.

56. Wong MT, Ong DE, Lim FS, et al:: A high-dimensional atlas of human $\mathrm{T}$ cell diversity reveals tissue-specific trafficking and cytokine signatures. Immunity 2016;45: 442-456.

57. Sathaliyawala T, Kubota M, Yudanin N, et al.: Distribution and compartmentalization of human circulating and tissue-resident memory T cell subsets. Immunity 2013;38: 187-197. 
58. Mueller SN, Gebhardt T, Carbone FR, Heath WR: Memory $\mathrm{T}$ cell subsets, migration patterns, and tissue residence. Annu Rev Immunol 2013;31:137-161.

59. Yukl SA, Shergill AK, Ho T, et al.: The distribution of HIV DNA and RNA in cell subsets differs in gut and blood of HIV-positive patients on ART: Implications for viral persistence. J Infect Dis 2013;208:1212-1220.

60. Mowat AM, Viney JL: The anatomical basis of intestinal immunity. Immunol Rev 1997;156:145-166.

61. Cerf-Bensussan N, Guy-Grand D: Intestinal intraepithelial lymphocytes. Gastroenterol Clin North Am 1991;20: 549-576.

62. Preza GC, Yang OO, Elliott J, Anton PA, Ochoa MT: T lymphocyte density and distribution in human colorectal mucosa, and inefficiency of current cell isolation protocols. PLoS One 2015;10:e0122723.

63. Mowat AM, Agace WW: Regional specialization within the intestinal immune system. Nat Rev Immunol 2014;14: 667-685.

64. Shale M, Schiering C, Powrie F: CD4(+) T-cell subsets in intestinal inflammation. Immunol Rev 2013;252:164-182.

65. Turner DL, Farber DL: Mucosal resident memory CD4 T cells in protection and immunopathology. Front Immunol 2014;5:331.

66. Crotty S: T follicular helper cell differentiation, function, and roles in disease. Immunity 2014;41:529-542.

67. Brenchley JM, Schacker TW, Ruff LE, et al.: CD4 ${ }^{+}$T cell depletion during all stages of HIV disease occurs predominantly in the gastrointestinal tract. J Exp Med 2004; 200:749-759.

68. Veazey RS, DeMaria M, Chalifoux LV, et al.: Gastrointestinal tract as a major site of $\mathrm{CD}^{+} \mathrm{T}$ cell depletion and viral replication in SIV infection. Science 1998;280: 427-431.

69. Mattapallil JJ, Douek DC, Hill B, Nishimura Y, Martin M, Roederer M: Massive infection and loss of memory CD4 ${ }^{+}$ $\mathrm{T}$ cells in multiple tissues during acute SIV infection. Nature 2005;434:1093-1097.

70. Li Q, Duan L, Estes JD, et al.: Peak SIV replication in resting memory $\mathrm{CD} 4^{+} \mathrm{T}$ cells depletes gut lamina propria CD4 ${ }^{+}$T cells. Nature 2005;434:1148-1152.

71. Guadalupe M, Reay E, Sankaran S, et al.: Severe CD4 ${ }^{+}$Tcell depletion in gut lymphoid tissue during primary human immunodeficiency virus type 1 infection and substantial delay in restoration following highly active antiretroviral therapy. J Virol 2003;77:11708-11717.

72. Doitsh G, Galloway NL, Geng X, et al.: Cell death by pyroptosis drives CD4 T-cell depletion in HIV-1 infection. Nature 2014;505:509-514.

73. Munoz-Arias I, Doitsh G, Yang Z, Sowinski S, Ruelas D, Greene WC: Blood-derived CD4 $\mathrm{T}$ cells naturally resist pyroptosis during abortive HIV-1 infection. Cell Host Microbe 2015;18:463-470.

74. Wu L, KewalRamani VN: Dendritic-cell interactions with HIV: Infection and viral dissemination. Nat Rev Immunol 2006;6:859-868.

75. Lapenta C, Boirivant M, Marini M, et al.: Human intestinal lamina propria lymphocytes are naturally permissive to HIV-1 infection. Eur J Immunol 1999;29: 1202-1208.

76. Veazey RS, Mansfield KG, Tham IC, et al: Dynamics of CCR5 expression by CD4(+) T cells in lymphoid tissues during simian immunodeficiency virus infection. $\mathrm{J}$ Virol 2000;74:11001-11007.
77. Anton PA, Elliott J, Poles MA, et al: : Enhanced levels of functional HIV-1 co-receptors on human mucosal $\mathrm{T}$ cells demonstrated using intestinal biopsy tissue. AIDS 2000;14:1761-1765.

78. Poles MA, Elliott J, Taing P, Anton PA, Chen IS: A preponderance of CCR5(+) CXCR4(+) mononuclear cells enhances gastrointestinal mucosal susceptibility to human immunodeficiency virus type 1 infection. J Virol 2001;75: 8390-8399.

79. Meng G, Sellers MT, Mosteller-Barnum M, Rogers TS, Shaw GM, Smith PD: Lamina propria lymphocytes, not macrophages, express CCR5 and CXCR4 and are the likely target cell for human immunodeficiency virus type 1 in the intestinal mucosa. J Infect Dis 2000;182:785-791.

80. Grivel JC, Elliott J, Lisco A, et al.: HIV-1 pathogenesis differs in rectosigmoid and tonsillar tissues infected ex vivo with CCR5- and CXCR4-tropic HIV-1. AIDS 2007;21: 1263-1272.

81. Veazey RS, Tham IC, Mansfield KG, et al.: Identifying the target cell in primary simian immunodeficiency virus (SIV) infection: Highly activated memory CD4(+) T cells are rapidly eliminated in early SIV infection in vivo. $\mathrm{J}$ Virol 2000;74:57-64.

82. Brenchley JM, Hill BJ, Ambrozak DR, et al.: T-cell subsets that harbor human immunodeficiency virus (HIV) in vivo: Implications for HIV pathogenesis. J Virol 2004;78: 1160-1168.

83. Picker LJ, Hagen SI, Lum R, et al.: Insufficient production and tissue delivery of $\mathrm{CD}^{+}$memory $\mathrm{T}$ cells in rapidly progressive simian immunodeficiency virus infection. $\mathrm{J}$ Exp Med 2004;200:1299-1314.

84. Okoye A, Meier-Schellersheim M, Brenchley JM, et al.: Progressive $\mathrm{CD}^{+}$central memory $\mathrm{T}$ cell decline results in $\mathrm{CD} 4^{+}$effector memory insufficiency and overt disease in chronic SIV infection. J Exp Med 2007;204:2171-2185.

85. Meng G, Wei X, Wu X, et al.: Primary intestinal epithelial cells selectively transfer R5 HIV-1 to $\mathrm{CCR}^{+}$cells. Nat Med 2002;8:150-156.

86. Connor RI, Sheridan KE, Ceradini D, Choe S, Landau NR: Change in coreceptor use correlates with disease progression in HIV-1-infected individuals. J Exp Med 1997;185:621-628.

87. Keele BF, Giorgi EE, Salazar-Gonzalez JF, et al.: Identification and characterization of transmitted and early founder virus envelopes in primary HIV-1 infection. Proc Natl Acad Sci U S A 2008;105:7552-7557.

88. McGowan I, Elliott J, Fuerst M, et al.: Increased HIV-1 mucosal replication is associated with generalized mucosal cytokine activation. J Acquir Immune Defic Syndr 2004;37:1228-1236.

89. Cicala C, Martinelli E, McNally JP, et al:: The integrin alpha4beta7 forms a complex with cell-surface CD4 and defines a T-cell subset that is highly susceptible to infection by HIV-1. Proc Natl Acad Sci U S A 2009;106: 20877-20882.

90. Byrareddy SN, Arthos J, Cicala C, et al.: Sustained virologic control in $\mathrm{SIV}^{+}$macaques after antiretroviral and alpha4beta7 antibody therapy. Science 2016;354: 197-202.

91. Guzzo C, Ichikawa D, Park C, et al.: Virion incorporation of integrin alpha4beta7 facilitates HIV-1 infection and intestinal homing. Sci Immunol 2017;2:pii: eaam7341.

92. Dillon SM, Lee EJ, Donovan AM, et al.: Enhancement of HIV-1 infection and intestinal $\mathrm{CD}^{+}{ }^{+} \mathrm{T}$ cell depletion ex 
vivo by gut microbes altered during chronic HIV-1 infection. Retrovirology 2016;13:5.

93. Assimakopoulos SF, Dimitropoulou D, Marangos M, Gogos CA: Intestinal barrier dysfunction in HIV infection: Pathophysiology, clinical implications and potential therapies. Infection 2014;42:951-959.

94. Nazli A, Chan O, Dobson-Belaire WN, et al.: Exposure to HIV-1 directly impairs mucosal epithelial barrier integrity allowing microbial translocation. PLoS Pathog 2010;6: e1000852.

95. Estes JD, Harris LD, Klatt NR, et al.: Damaged intestinal epithelial integrity linked to microbial translocation in pathogenic simian immunodeficiency virus infections. PLoS Pathog 2010;6:e1001052.

96. Marchetti G, Bellistri GM, Borghi E, et al:: Microbial translocation is associated with sustained failure in $\mathrm{CD} 4^{+}$ $\mathrm{T}$-cell reconstitution in $\mathrm{HIV}$-infected patients on longterm highly active antiretroviral therapy. AIDS 2008;22: 2035-2038.

97. Favre D, Mold J, Hunt PW, et al.: Tryptophan catabolism by indoleamine 2,3-dioxygenase 1 alters the balance of TH17 to regulatory T cells in HIV disease. Sci Transl Med 2010;2:32ra6.

98. Page EE, Greathead L, Metcalf R, et al.: Loss of Th22 cells is associated with increased immune activation and IDO-1 activity in HIV-1 infection. J Acquir Immune Defic Syndr 2014;67:227-235.

99. Lane HC, Masur H, Edgar LC, Whalen G, Rook AH, Fauci AS: Abnormalities of B-cell activation and immunoregulation in patients with the acquired immunodeficiency syndrome. N Engl J Med 1983;309:453-458.

100. Hazenberg MD, Stuart JW, Otto SA, et al:: T-cell division in human immunodeficiency virus (HIV)-1 infection is mainly due to immune activation: A longitudinal analysis in patients before and during highly active antiretroviral therapy (HAART). Blood 2000;95:249-255.

101. Hellerstein M, Hanley MB, Cesar D, et al.: Directly measured kinetics of circulating $\mathrm{T}$ lymphocytes in normal and HIV-1-infected humans. Nat Med 1999;5:83-89.

102. Reuter MA, Pombo C, Betts MR: Cytokine production and dysregulation in HIV pathogenesis: Lessons for development of therapeutics and vaccines. Cytokine Growth Factor Rev 2012;23:181-191.

103. McCune JM, Hanley MB, Cesar D, et al:: Factors influencing $\mathrm{T}$-cell turnover in HIV-1-seropositive patients. J Clin Invest 2000;105:R1-R8.

104. Gordon SN, Cervasi B, Odorizzi P, et al: Disruption of intestinal $\mathrm{CD}^{+} \mathrm{T}$ cell homeostasis is a key marker of systemic $\mathrm{CD}^{+} \mathrm{T}$ cell activation in HIV-infected individuals. J Immunol 2010;185:5169-5179.

105. Douek DC, McFarland RD, Keiser PH, et al:: Changes in thymic function with age and during the treatment of HIV infection. Nature 1998;396:690-695.

106. Dion ML, Poulin JF, Bordi R, et al.: HIV infection rapidly induces and maintains a substantial suppression of thymocyte proliferation. Immunity 2004;21:757-768.

107. Schacker TW, Nguyen PL, Beilman GJ, et al.: Collagen deposition in HIV-1 infected lymphatic tissues and T cell homeostasis. J Clin Invest 2002;110:1133-1139.

108. Estes J, Baker JV, Brenchley JM, et al.: Collagen deposition limits immune reconstitution in the gut. J Infect Dis 2008;198:456-464.

109. Sankaran S, Guadalupe M, Reay E, et al:: Gut mucosal $\mathrm{T}$ cell responses and gene expression correlate with protection against disease in long-term HIV-1-infected nonprogressors. Proc Natl Acad Sci U S A 2005;102: 9860-9865.

110. Wang H, Kotler DP: HIV enteropathy and aging: Gastrointestinal immunity, mucosal epithelial barrier, and microbial translocation. Curr Opin HIV AIDS 2014;9: 309-316.

111. Hunt PW: HIV and aging: Emerging research issues. Curr Opin HIV AIDS 2014;9:302-308.

112. Mehandru S, Poles MA, Tenner-Racz K, et al.: Primary HIV-1 infection is associated with preferential depletion of $\mathrm{CD}^{+} \mathrm{T}$ lymphocytes from effector sites in the gastrointestinal tract. J Exp Med 2004;200:761-770.

113. Yukl SA, Shergill AK, Girling V, et al:: Site-specific differences in $\mathrm{T}$ cell frequencies and phenotypes in the blood and gut of HIV-uninfected and ART-treated $\mathrm{HIV}^{+}$ adults. PLoS One 2015;10:e0121290.

114. Talal AH, Monard S, Vesanen M, et al.: Virologic and immunologic effect of antiretroviral therapy on HIV-1 in gut-associated lymphoid tissue. J Acquir Immune Defic Syndr 2001;26:1-7.

115. Fackler OT, Schafer M, Schmidt W, et al.: HIV-1 p24 but not proviral load is increased in the intestinal mucosa compared with the peripheral blood in HIV-infected patients. AIDS 1998;12:139-146.

116. d'Ettorre G, Paiardini M, Zaffiri L, et al.: HIV persistence in the gut mucosa of HIV-infected subjects undergoing antiretroviral therapy correlates with immune activation and increased levels of LPS. Curr HIV Res 2011;9:148-153.

117. Mehandru S, Poles MA, Tenner-Racz K, et al.: Mechanisms of gastrointestinal $\mathrm{CD}^{+} \mathrm{T}$-cell depletion during acute and early human immunodeficiency virus type 1 infection. J Virol 2007;81:599-612.

118. Di Stefano M, Favia A, Monno L, et al.: Intracellular and cell-free (infectious) HIV-1 in rectal mucosa. J Med Virol 2001;65:637-643.

119. Belmonte L, Olmos M, Fanin A, et al.: The intestinal mucosa as a reservoir of HIV-1 infection after successful HAART. AIDS 2007;21:2106-2108.

120. Lafeuillade A, Cheret A, Hittinger G, et al: Rectal cellassociated HIV-1 RNA: A new marker ready for the clinic. HIV Clin Trials 2009;10:324-327.

121. Tincati C, Biasin M, Bandera A, et al.: Early initiation of highly active antiretroviral therapy fails to reverse immunovirological abnormalities in gut-associated lymphoid tissue induced by acute HIV infection. Antivir Ther 2009; 14:321-330.

122. Chun TW, Nickle DC, Justement JS, et al.: Persistence of HIV in gut-associated lymphoid tissue despite long-term antiretroviral therapy. J Infect Dis 2008;197:714-720.

123. Eriksson S, Graf EH, Dahl V, et al.: Comparative analysis of measures of viral reservoirs in HIV-1 eradication studies. PLoS Pathog 2013;9:e1003174.

124. Yukl SA, Gianella S, Sinclair E, et al.: Differences in HIV burden and immune activation within the gut of HIVpositive patients receiving suppressive antiretroviral therapy. J Infect Dis 2010;202:1553-1561.

125. Poles MA, Boscardin WJ, Elliott J, et al.: Lack of decay of HIV-1 in gut-associated lymphoid tissue reservoirs in maximally suppressed individuals. J Acquir Immune Defic Syndr 2006;43:65-68.

126. Santangelo PJ, Rogers KA, Zurla C, et al:: Whole-body immunoPET reveals active SIV dynamics in viremic and 
antiretroviral therapy-treated macaques. Nat Methods 2015;12:427-432.

127. Deere JD, Kauffman RC, Cannavo E, et al.: Analysis of multiply spliced transcripts in lymphoid tissue reservoirs of rhesus macaques infected with RT-SHIV during HAART. PLoS One 2014;9:e87914.

128. Katzenstein TL, Petersen AB, Storgaard M, et al.: Phylogeny and resistance profiles of HIV-1 POL sequences from rectal biopsies and blood. J Med Virol 2010;82: 1103-1109.

129. Lewis MJ, Frohnen P, Ibarrondo FJ, et al:: HIV-1 Nef sequence and functional compartmentalization in the gut is not due to differential cytotoxic T lymphocyte selective pressure. PLoS One 2013;8:e75620.

130. van Marle G, Gill MJ, Kolodka D, McManus L, Grant T, Church DL: Compartmentalization of the gut viral reservoir in HIV-1 infected patients. Retrovirology 2007;4:87.

131. Avettand-Fenoel V, Hocqueloux L, Muller-Trutwin M, et al.: Greater diversity of HIV DNA variants in the rectum compared to variants in the blood in patients without HAART. J Med Virol 2011;83:1499-1507.

132. Imamichi H, Degray G, Dewar RL, et al.: Lack of compartmentalization of HIV-1 quasispecies between the gut and peripheral blood compartments. J Infect Dis 2011;204: 309-314.

133. McElrath MJ, Smythe K, Randolph-Habecker J, et al: Comprehensive assessment of HIV target cells in the distal human gut suggests increasing HIV susceptibility toward the anus. J Acquir Immune Defic Syndr 2013;63: 263-271.

134. Clayton KL, Garcia JV, Clements JE, Walker BD: HIV infection of macrophages: Implications for pathogenesis and cure. Pathog Immun 2017;2:179-192.

135. Baxter AE, Russell RA, Duncan CJ, et al:: Macrophage infection via selective capture of HIV-1-infected $\mathrm{CD}^{+}{ }^{+} \mathrm{T}$ cells. Cell Host Microbe 2014;16:711-721.

136. DiNapoli SR, Ortiz AM, Wu F, et al.: Tissue-resident macrophages can contain replication-competent virus in antiretroviral-naive, SIV-infected Asian macaques. JCI Insight 2017;2:e91214.

137. Calantone N, Wu F, Klase Z, et al:: Tissue myeloid cells in SIV-infected primates acquire viral DNA through phagocytosis of infected T cells. Immunity 2014;41:493-502.

138. Lewin-Smith M, Wahl SM, Orenstein JM: Human immunodeficiency virus-rich multinucleated giant cells in the colon: A case report with transmission electron microscopy, immunohistochemistry, and in situ hybridization. Mod Pathol 1999;12:75-81.

139. Zalar A, Figueroa MI, Ruibal-Ares B, et al.: Macrophage HIV-1 infection in duodenal tissue of patients on long term HAART. Antiviral Res 2010;87:269-271.

140. Smith PD, Meng G, Shaw GM, Li L: Infection of gastrointestinal tract macrophages by HIV-1. J Leukoc Biol 1997;62:72-77.

141. Li L, Meng G, Graham MF, Shaw GM, Smith PD: Intestinal macrophages display reduced permissiveness to human immunodeficiency virus 1 and decreased surface CCR5. Gastroenterology 1999;116:1043-1053.

142. Wong JK, Yukl SA: Tissue reservoirs of HIV. Curr Opin HIV AIDS 2016;11:362-370.

143. Yukl SA, Sinclair E, Somsouk M, et al:: A comparison of methods for measuring rectal HIV levels suggests that HIV DNA resides in cells other than $\mathrm{CD}^{+} \mathrm{T}$ cells, including myeloid cells. AIDS 2014;28:439-442.
144. $\mathrm{Xu} \mathrm{Y,} \mathrm{Zhu} \mathrm{H,} \mathrm{Wilcox} \mathrm{CK,} \mathrm{et} \mathrm{al.:} \mathrm{Blood} \mathrm{monocytes} \mathrm{harbor}$ HIV type 1 strains with diversified phenotypes including macrophage-specific CCR5 virus. J Infect Dis 2008;197: 309-318.

145. Ochsenbauer C, Edmonds TG, Ding H, et al.: Generation of transmitted/founder HIV-1 infectious molecular clones and characterization of their replication capacity in CD4 T lymphocytes and monocyte-derived macrophages. J Virol 2012;86:2715-2728.

146. Honeycutt JB, Wahl A, Baker C, et al.: Macrophages sustain HIV replication in vivo independently of $\mathrm{T}$ cells. J Clin Invest 2016;126:1353-1366.

147. Honeycutt JB, Thayer WO, Baker CE, et al.: HIV persistence in tissue macrophages of humanized myeloidonly mice during antiretroviral therapy. Nat Med 2017;23: 638-643.

148. Phetsouphanh $\mathrm{C}, \mathrm{Xu}$ Y, Zaunders J: CD4 T cells mediate both positive and negative regulation of the immune response to HIV infection: Complex role of $\mathrm{T}$ follicular helper cells and regulatory $\mathrm{T}$ cells in pathogenesis. Front Immunol 2014;5:681.

149. Kinter AL, Hennessey M, Bell A, et al.: CD25(+)CD4(+) regulatory $\mathrm{T}$ cells from the peripheral blood of asymptomatic HIV-infected individuals regulate $\mathrm{CD} 4(+)$ and CD8(+) HIV-specific $\mathrm{T}$ cell immune responses in vitro and are associated with favorable clinical markers of disease status. J Exp Med 2004;200:331-343.

150. Eggena MP, Barugahare B, Jones N, et al.: Depletion of regulatory $\mathrm{T}$ cells in HIV infection is associated with immune activation. J Immunol 2005;174:4407-4414.

151. Montes M, Lewis DE, Sanchez C, et al.: Foxp3 ${ }^{+}$regulatory $\mathrm{T}$ cells in antiretroviral-naive HIV patients. AIDS 2006;20:1669-1671.

152. Card CM, McLaren PJ, Wachihi C, Kimani J, Plummer FA, Fowke KR: Decreased immune activation in resistance to HIV-1 infection is associated with an elevated frequency of CD4(+)CD25(+)FOXP3(+) regulatory T cells. J Infect Dis 2009;199:1318-1322.

153. Weiss L, Donkova-Petrini V, Caccavelli L, Balbo M, Carbonneil C, Levy Y: Human immunodeficiency virus-driven expansion of $\mathrm{CD} 4^{+} \mathrm{CD} 25^{+}$regulatory T cells, which suppress HIV-specific CD4 T-cell responses in HIV-infected patients. Blood 2004; 104:3249-3256.

154. Nilsson J, Boasso A, Velilla PA, et al.: HIV-1-driven regulatory T-cell accumulation in lymphoid tissues is associated with disease progression in HIV/AIDS. Blood 2006;108:3808-3817.

155. Xing $\mathrm{S}, \mathrm{Fu} \mathrm{J}$, Zhang $\mathrm{Z}$, et al:: Increased turnover of FoxP3high regulatory $\mathrm{T}$ cells is associated with hyperactivation and disease progression of chronic HIV-1 infection. J Acquir Immune Defic Syndr 2010;54:455-462.

156. Suchard MS, Mayne E, Green VA, et al.: FOXP3 expression is upregulated in CD4T cells in progressive HIV-1 infection and is a marker of disease severity. PLoS One 2010;5:e11762.

157. Chase AJ, Sedaghat AR, German JR, et al.: Severe depletion of $\mathrm{CD}^{+} \mathrm{CD} 25^{+}$regulatory $\mathrm{T}$ cells from the intestinal lamina propria but not peripheral blood or lymph nodes during acute simian immunodeficiency virus infection. J Virol 2007;81:12748-12757.

158. Mercer F, Khaitan A, Kozhaya L, Aberg JA, Unutmaz D: Differentiation of IL-17-producing effector and regulatory human $\mathrm{T}$ cells from lineage-committed naive precursors. J Immunol 2014;193:1047-1054. 
159. Moreno-Fernandez ME, Zapata W, Blackard JT, Franchini $\mathrm{G}$, Chougnet CA: Human regulatory $\mathrm{T}$ cells are targets for human immunodeficiency Virus (HIV) infection, and their susceptibility differs depending on the HIV type 1 strain. J Virol 2009;83:12925-12933.

160. Dunham RM, Cervasi B, Brenchley JM, et al.: CD127 and $\mathrm{CD} 25$ expression defines $\mathrm{CD}^{+} \mathrm{T}$ cell subsets that are differentially depleted during HIV infection. J Immunol 2008;180:5582-5592.

161. Schulze Zur Wiesch J, Thomssen A, Hartjen P, et al:: Comprehensive analysis of frequency and phenotype of $\mathrm{T}$ regulatory cells in HIV infection: CD39 expression of FoxP3 $3^{+} \mathrm{T}$ regulatory cells correlates with progressive disease. J Virol 2011;85:1287-1297.

162. Jiao YM, Liu CE, Luo LJ, et al.: $\mathrm{CD} 4^{+} \mathrm{CD} 25^{+} \mathrm{CD} 127$ regulatory cells play multiple roles in maintaining HIV-1 p24 production in patients on long-term treatment: HIV-1 p24-producing cells and suppression of anti-HIV immunity. Int J Infect Dis 2015;37:42-49.

163. DaFonseca S, Niessl J, Pouvreau S, et al.: Impaired Th17 polarization of phenotypically naive CD4(+) T-cells during chronic HIV-1 infection and potential restoration with early ART. Retrovirology 2015;12:38.

164. He T, Brocca-Cofano E, Policicchio BB, et al.: Cutting edge: $T$ regulatory cell depletion reactivates latent simian immunodeficiency virus (SIV) in controller macaques while boosting SIV-specific T lymphocytes. J Immunol 2016;197:4535-4539.

165. Zaunders JJ, Ip S, Munier ML, et al.: Infection of CD $127^{+}$ (interleukin-7 receptor $^{+}$) $\mathrm{CD}^{+}$cells and overexpression of CTLA-4 are linked to loss of antigen-specific CD4 T cells during primary human immunodeficiency virus type 1 infection. J Virol 2006;80:10162-10172.

166. Korn T, Bettelli E, Oukka M, Kuchroo VK: IL-17 and Th17 Cells. Annu Rev Immunol 2009;27:485-517.

167. Acosta-Rodriguez EV, Rivino L, Geginat J, et al:: Surface phenotype and antigenic specificity of human interleukin 17-producing T helper memory cells. Nat Immunol 2007;8: 639-646.

168. Annunziato F, Cosmi L, Santarlasci V, et al.: Phenotypic and functional features of human Th17 cells. J Exp Med 2007;204:1849-1861.

169. Singh SP, Zhang HH, Foley JF, Hedrick MN, Farber JM: Human T cells that are able to produce IL-17 express the chemokine receptor CCR6. J Immunol 2008;180:214-221.

170. Wang C, Kang SG, Lee J, Sun Z, Kim CH: The roles of CCR6 in migration of Th17 cells and regulation of effector T-cell balance in the gut. Mucosal Immunol 2009;2:173-183.

171. Gosselin A, Monteiro P, Chomont N, et al.: Peripheral blood $\mathrm{CCR}^{+} \mathrm{CCR}^{+}$and $\mathrm{CXCR}^{+}{ }^{+} \mathrm{CCR}^{+}{ }^{+} \mathrm{CD} 4^{+} \mathrm{T}$ cells are highly permissive to HIV-1 infection. J Immunol 2010; 184:1604-1616.

172. Gosselin A, Wiche Salinas TR, Planas D, et al.: HIV persists in $\mathrm{CCR}^{+} \mathrm{CD}^{+} \mathrm{T}$ cells from colon and blood during antiretroviral therapy. AIDS 2017;31:35-48.

173. Khoury G, Anderson JL, Fromentin R, et al.: Persistence of integrated HIV DNA in $\mathrm{CXCR}^{+} \mathrm{CCR}^{+}$memory $\mathrm{CD}^{+}{ }^{\mathrm{T}}$ cells in HIV-infected individuals on antiretroviral therapy. AIDS 2016;30:1511-1520.

174. Muranski P, Borman ZA, Kerkar SP, et al.: Th17 cells are long lived and retain a stem cell-like molecular signature. Immunity 2011;35:972-985.

175. Kryczek I, Zhao E, Liu Y, et al.: Human TH17 cells are longlived effector memory cells. Sci Transl Med 2011;3:104ra0.
176. Sun H, Kim D, Li X, et al:: Th1/17 polarization of CD4 T cells supports HIV-1 persistence during antiretroviral therapy. J Virol 2015;89:11284-11293.

177. Wacleche VS, Goulet JP, Gosselin A, et al.: New insights into the heterogeneity of Th17 subsets contributing to HIV-1 persistence during antiretroviral therapy. Retrovirology 2016;13:59.

178. Chege D, Sheth PM, Kain T, et al:: Sigmoid Th17 populations, the HIV latent reservoir, and microbial translocation in men on long-term antiretroviral therapy. AIDS 2011;25:741-749.

179. Salgado M, Rallon NI, Rodes B, Lopez M, Soriano V, Benito JM: Long-term non-progressors display a greater number of Th17 cells than HIV-infected typical progressors. Clin Immunol 2011;139:110-114.

180. Bernier A, Cleret-Buhot A, Zhang Y, et al:: Transcriptional profiling reveals molecular signatures associated with HIV permissiveness in Th1Th17 cells and identifies peroxisome proliferator-activated receptor gamma as an intrinsic negative regulator of viral replication. Retrovirology 2013;10:160.

181. Cameron PU, Saleh S, Sallmann G, et al.: Establishment of HIV-1 latency in resting $\mathrm{CD}^{+} \mathrm{T}$ cells depends on chemokine-induced changes in the actin cytoskeleton. Proc Natl Acad Sci U S A 2010;107:16934-16939.

182. Routy JP, Mehraj V, Vyboh K, Cao W, Kema I, Jenabian MA: Clinical relevance of kynurenine pathway in HIV/ AIDS: An immune checkpoint at the crossroads of metabolism and inflammation. AIDS Rev 2015;17:96-106.

183. Sonnenberg GF, Fouser LA, Artis D: Border patrol: Regulation of immunity, inflammation and tissue homeostasis at barrier surfaces by IL-22. Nat Immunol 2011; 12:383-390.

184. Xu H, Wang X, Veazey RS: Th17 cells coordinate with Th22 cells in maintaining homeostasis of intestinal tissues and both are depleted in SIV-infected macaques. J AIDS Clin Res 2014;5:302.

185. Leung JM, Davenport M, Wolff MJ, et al.: IL-22producing $\mathrm{CD}^{+}$cells are depleted in actively inflamed colitis tissue. Mucosal Immunol 2014;7:124-133.

186. Ryan ES, Micci L, Fromentin R, et al.: Loss of function of intestinal IL-17 and IL-22 producing cells contributes to inflammation and viral persistence in SIV-infected rhesus macaques. PLoS Pathog 2016;12:e1005412.

187. Micci L, Ryan ES, Fromentin R, et al.: Interleukin-21 combined with ART reduces inflammation and viral reservoir in SIV-infected macaques. J Clin Invest 2015;125: 4497-4513.

188. Breitfeld D, Ohl L, Kremmer E, et al.: Follicular B helper $\mathrm{T}$ cells express $\mathrm{CXC}$ chemokine receptor 5, localize to B cell follicles, and support immunoglobulin production. J Exp Med 2000;192:1545-1552.

189. Schaerli P, Willimann K, Lang AB, Lipp M, Loetscher $\mathrm{P}$, Moser B: CXC chemokine receptor 5 expression defines follicular homing $\mathrm{T}$ cells with $\mathrm{B}$ cell helper function. J Exp Med 2000;192:1553-1562.

190. Chtanova T, Tangye SG, Newton R, et al.: T follicular helper cells express a distinctive transcriptional profile, reflecting their role as non-Th1/Th2 effector cells that provide help for B cells. J Immunol 2004;173:68-78.

191. Johnston RJ, Poholek AC, DiToro D, et al.: Bcl6 and Blimp-1 are reciprocal and antagonistic regulators of $\mathrm{T}$ follicular helper cell differentiation. Science 2009;325: 1006-1010. 
192. Kim CH, Rott LS, Clark-Lewis I, Campbell DJ, Wu L, Butcher EC: Subspecialization of $\mathrm{CXCR}^{+} \mathrm{T}$ cells: B helper activity is focused in a germinal center-localized subset of CXCR5 $^{+}$T cells. J Exp Med 2001;193:1373-1381.

193. Ansel KM, McHeyzer-Williams LJ, Ngo VN, McHeyzerWilliams MG, Cyster JG: In vivo-activated CD4 T cells upregulate CXC chemokine receptor 5 and reprogram their response to lymphoid chemokines. J Exp Med 1999;190: 1123-1134.

194. Ma CS, Suryani S, Avery DT, et al.: Early commitment of naive human $\mathrm{CD} 4(+) \mathrm{T}$ cells to the $\mathrm{T}$ follicular helper $(\mathrm{T}(\mathrm{FH})$ ) cell lineage is induced by IL-12. Immunol Cell Biol 2009;87:590-600.

195. Xu Y, Weatherall C, Bailey M, et al.: Simian immunodeficiency virus infects follicular helper CD4 T cells in lymphoid tissues during pathogenic infection of pigtail macaques. J Virol 2013;87:3760-3773.

196. Kim CH, Lim HW, Kim JR, Rott L, Hillsamer P, Butcher EC: Unique gene expression program of human germinal center T helper cells. Blood 2004;104:1952-1960.

197. Kohler SL, Pham MN, Folkvord JM, et al:: Germinal center $\mathrm{T}$ follicular helper cells are highly permissive to HIV-1 and alter their phenotype during virus replication. J Immunol 2016;196:2711-2722.

198. Bekele Y, Amu S, Bobosha K, et al.: Impaired phenotype and function of $\mathrm{T}$ follicular helper cells in HIV-1-infected children receiving ART. Medicine 2015;94:e1125.

199. Petrovas C, Yamamoto T, Gerner MY, et al.: CD4 T follicular helper cell dynamics during SIV infection. J Clin Invest 2012;122:3281-3294.

200. Perreau M, Savoye AL, De Crignis E, et al:: Follicular helper T cells serve as the major CD4 T cell compartment for HIV-1 infection, replication, and production. J Exp Med 2013;210:143-156.

201. Hong JJ, Amancha PK, Rogers K, Ansari AA, Villinger F: Spatial alterations between CD4(+) T follicular helper, $\mathrm{B}$, and CD8(+) $\mathrm{T}$ cells during simian immunodeficiency virus infection: T/B cell homeostasis, activation, and potential mechanism for viral escape. J Immunol 2012;188: 3247-3256.

202. Colineau L, Rouers A, Yamamoto T, et al.: HIV-infected spleens present altered follicular helper $\mathrm{T}$ cell ( $\mathrm{Tfh}$ ) subsets and skewed B cell maturation. PLoS One 2015;10: e0140978.

203. Lindqvist M, van Lunzen J, Soghoian DZ, et al.: Expansion of HIV-specific $\mathrm{T}$ follicular helper cells in chronic HIV infection. J Clin Invest 2012;122:3271-3280.

204. Brenchley JM, Vinton C, Tabb B, et al:: Differential infection patterns of $\mathrm{CD}^{+} \mathrm{T}$ cells and lymphoid tissue viral burden distinguish progressive and nonprogressive lentiviral infections. Blood 2012;120:4172-4181.

205. Klatt NR, Vinton CL, Lynch RM, et al.: SIV infection of rhesus macaques results in dysfunctional T- and B-cell responses to neo and recall Leishmania major vaccination. Blood 2011;118:5803-5812.

206. Fukazawa Y, Lum R, Okoye AA, et al.: B cell follicle sanctuary permits persistent productive simian immunodeficiency virus infection in elite controllers. Nat Med 2015;21:132-139.

207. Moukambi F, Rabezanahary H, Rodrigues V, et al.: Early loss of splenic Tfh cells in SIV-infected rhesus macaques. PLoS Pathog 2015;11:e1005287.

208. Rahmberg AR, Rajakumar PA, Billingsley JM, Gill SP, Johnson RP: Single cell transcriptional profiling reveals a novel population of mucosal TFH cells. Conference on Retroviruses and Opportunistic Infections. IAS-USA, Seattle, WA, 2017.

209. Li S, Folkvord JM, Rakasz EG, et al.: Simian immunodeficiency virus-producing cells in follicles are partially suppressed by $\mathrm{CD}^{+}$cells in vivo. J Virol 2016;90:1116811180.

210. He R, Hou S, Liu C, et al.: Follicular CXCR5 ${ }^{-}$expressing CD8(+) T cells curtail chronic viral infection. Nature 2016; 537:412-428.

211. Leong YA, Chen Y, Ong HS, et al.: CXCR5(+) follicular cytotoxic T cells control viral infection in B cell follicles. Nature 2016;17:1187-1196.

212. Quigley MF, Gonzalez VD, Granath A, Andersson J, Sandberg JK: CXCR5 ${ }^{+} \mathrm{CCR}^{-}$CD8 $\mathrm{T}$ cells are early effector memory cells that infiltrate tonsil B cell follicles. Eur J Immunol 2007;37:3352-3362.

213. Ayala VI, Deleage C, Trivett MT, et al.: CXCR5-dependent entry of CD8 T cells into rhesus macaque B-cell follicles achieved through T-cell engineering. J Virol 2017;91:pii: e02507-16.

214. Banga R, Procopio FA, Noto A, et al.: PD-1(+) and follicular helper $\mathrm{T}$ cells are responsible for persistent HIV-1 transcription in treated aviremic individuals. Nat Med 2016;22:754-761.

215. Fromentin R, Bakeman W, Lawani MB, et al.: $\mathrm{CD} 4^{+}$ T cells expressing PD-1, TIGIT and LAG-3 contribute to HIV persistence during ART. PLoS Pathog 2016;12: e1005761.

216. Cubas RA, Mudd JC, Savoye AL, et al.: Inadequate T follicular cell help impairs B cell immunity during HIV infection. Nat Med 2013;19:494-499.

217. Lederman MM, Calabrese L, Funderburg NT, et al.: Immunologic failure despite suppressive antiretroviral therapy is related to activation and turnover of memory CD4 cells. J Infect Dis 2011;204:1217-1226.

218. Zaunders J, Danta M, Bailey M, et al.: $\mathrm{CD}^{+} \mathrm{T}$ follicular helper and $\mathrm{IgA}^{+} \mathrm{B}$ cell numbers in gut biopsies from HIV-infected subjects on antiretroviral therapy are similar to HIV-uninfected individuals. Front Immunol 2016; $7: 438$.

219. Pallikkuth S, Sharkey M, Babic DZ, et al.: Peripheral T follicular helper cells are the major HIV reservoir within central memory CD4 $\mathrm{T}$ cells in peripheral blood from chronically HIV-infected individuals on combination antiretroviral therapy. J Virol 2015;90:2718-2728.

220. Allam A, Majji S, Peachman K, et al.: TFH cells accumulate in mucosal tissues of humanized-DRAG mice and are highly permissive to HIV-1. Sci Rep 2015;5:10443.

221. Spencer J, MacDonald TT, Finn T, Isaacson PG: The development of gut associated lymphoid tissue in the terminal ileum of fetal human intestine. Clin Exp Immunol 1986; 64:536-543.

222. Bjerke K, Brandtzaeg P, Fausa O: T cell distribution is different in follicle-associated epithelium of human Peyer's patches and villous epithelium. Clin Exp Immunol 1988;74:270-275.

223. Flynn JK, Paukovics G, Cashin K, et al:: Quantifying susceptibility of $\mathrm{CD}^{+}{ }^{+}$stem memory T-cells to infection by laboratory adapted and clinical HIV-1 strains. Viruses 2014;6:709-726.

224. Bacchus C, Cheret A, Avettand-Fenoel V, et al.: A single HIV-1 cluster and a skewed immune homeostasis drive the early spread of HIV among resting $\mathrm{CD} 4^{+}$cell subsets 
within one month post-infection. PLoS One 2013;8: e64219.

225. Ganesan A, Chattopadhyay PK, Brodie TM, et al.: Immunologic and virologic events in early HIV infection predict subsequent rate of progression. $\mathrm{J}$ Infect Dis 2010;201:272-284.

226. Puertas MC, Noguera-Julian M, Massanella M, et al.: Lack of concordance between residual viremia and viral variants driving de novo infection of CD4(+) T cells on ART. Retrovirology 2016;13:51.

227. Baxter AE, Niessl J, Fromentin R, et al.: Single-Cell Characterization of Viral Translation-Competent Reservoirs in HIV-Infected Individuals. Cell Host Microbe 2016;20:368-380.

228. Descours B, Avettand-Fenoel V, Blanc C, et al.: Immune responses driven by protective human leukocyte antigen alleles from long-term nonprogressors are associated with low HIV reservoir in central memory CD4 T cells. Clin Infect Dis 2012;54:1495-1503.

229. Soriano-Sarabia N, Bateson RE, Dahl NP, et al:: Quantitation of replication-competent HIV-1 in populations of resting CD4 ${ }^{+}$T cells. J Virol 2014;88:14070-14077.

230. Lassen KG, Hebbeler AM, Bhattacharyya D, Lobritz MA, Greene WC: A flexible model of HIV-1 latency permitting evaluation of many primary CD4 T-cell reservoirs. PLoS One 2012; 7:e30176.

231. Breton G, Chomont N, Takata H, et al.: Programmed death-1 is a marker for abnormal distribution of naive/ memory $\mathrm{T}$ cell subsets in HIV-1 infection. $\mathrm{J}$ Immunol 2013;191:2194-2204.

232. Mueller SN, Mackay LK: Tissue-resident memory T cells: Local specialists in immune defence. Nat Rev Immunol 2016;16:79-89.

233. Schenkel JM, Masopust D: Tissue-resident memory $\mathrm{T}$ cells. Immunity 2014;41:886-897.

234. Cauley LS, Lefrancois L: Guarding the perimeter: Protection of the mucosa by tissue-resident memory $\mathrm{T}$ cells. Mucosal Immunol 2013;6:14-23.

235. Iijima N, Iwasaki A: T cell memory. A local macrophage chemokine network sustains protective tissue-resident memory CD4 T cells. Science 2014;346:93-98.

236. Purwar R, Campbell J, Murphy G, Richards WG, Clark RA, Kupper TS: Resident memory T cells (T(RM)) are abundant in human lung: Diversity, function, and antigen specificity. PLoS One 2011;6:e16245.

237. Suzuki R, Nakao A, Kanamaru Y, Okumura K, Ogawa H, $\mathrm{Ra} C$ : Localization of intestinal intraepithelial $\mathrm{T}$ lymphocytes involves regulation of alphaEbeta7 expression by transforming growth factor-beta. Int Immunol 2002;14:339-345.

238. Kang SG, Park J, Cho JY, Ulrich B, Kim CH: Complementary roles of retinoic acid and TGF-betal in coordinated expression of mucosal integrins by $\mathrm{T}$ cells. Mucosal Immunol 2011;4:66-82.

239. Casey KA, Fraser KA, Schenkel JM, et al.: Antigenindependent differentiation and maintenance of effectorlike resident memory $\mathrm{T}$ cells in tissues. $\mathrm{J}$ Immunol 2012;188:4866-4875.

240. Hadley GA, Higgins JM: Integrin alphaEbeta7: Molecular features and functional significance in the immune system. Adv Exp Med Biol 2014;819:97-110.

241. Thome JJ, Farber DL: Emerging concepts in tissueresident $\mathrm{T}$ cells: Lessons from humans. Trends Immunol 2015;36:428-435.
242. Couturier J, Suliburk JW, Brown JM, et al.: Human adipose tissue as a reservoir for memory $\mathrm{CD} 4^{+} \mathrm{T}$ cells and HIV. AIDS 2015;29:667-674.

243. Damouche A, Lazure T, Avettand-Fenoel V, et al.: Adipose tissue is a neglected viral reservoir and an inflammatory site during chronic HIV and SIV infection. PLoS Pathog 2015;11:e1005153.

244. Joag VR, McKinnon LR, Liu J, et al.: Identification of preferential $\mathrm{CD}^{+}{ }^{+} \mathrm{T}$-cell targets for HIV infection in the cervix. Mucosal Immunol 2016;9:1-12.

245. Lee GQ, Lichterfeld M: Diversity of HIV-1 reservoirs in $\mathrm{CD}^{+}$T-cell subpopulations. Curr Opin HIV AIDS 2016;11:383-387.

246. Constant P, Davodeau F, Peyrat MA, et al.: Stimulation of human gamma delta $\mathrm{T}$ cells by nonpeptidic mycobacterial ligands. Science 1994;264:267-270.

247. Hayday AC: [gamma][delta] cells: A right time and a right place for a conserved third way of protection. Annu Rev Immunol 2000;18:975-1026.

248. Chien YH, Iwashima M, Wettstein DA, et al:: T-cell receptor delta gene rearrangements in early thymocytes. Nature 1987;330:722-727.

249. Born W, Miles C, White J, et al.: Peptide sequences of Tcell receptor delta and gamma chains are identical to predicted X and gamma proteins. Nature 1987;330:572-574.

250. Bukowski JF, Morita CT, Brenner MB: Human gamma delta $\mathrm{T}$ cells recognize alkylamines derived from microbes, edible plants, and tea: Implications for innate immunity. Immunity 1999;11:57-65.

251. Morita CT, Verma S, Aparicio P, Martinez C, Spits H, Brenner MB: Functionally distinct subsets of human gamma/delta T cells. Eur J Immunol 1991;21:2999-3007.

252. Vincent MS, Roessner K, Sellati T, et al.: Lyme arthritis synovial gamma delta $\mathrm{T}$ cells respond to Borrelia burgdorferi lipoproteins and lipidated hexapeptides. J Immunol 1998;161:5762-5771.

253. Deetz CO, Hebbeler AM, Propp NA, Cairo C, Tikhonov I, Pauza CD: Gamma interferon secretion by human Vgamma2Vdelta2 $\mathrm{T}$ cells after stimulation with antibody against the T-cell receptor plus the Toll-Like receptor 2 agonist Pam3Cys. Infect Immun 2006;74:4505-4511.

254. Gober HJ, Kistowska M, Angman L, Jeno P, Mori L, De Libero G: Human T cell receptor gammadelta cells recognize endogenous mevalonate metabolites in tumor cells. J Exp Med 2003;197:163-168.

255. Poccia F, Agrati C, Martini F, Capobianchi MR, Wallace M, Malkovsky M: Antiviral reactivities of gammadelta T cells. Microbes Infect 2005;7:518-528.

256. Poles MA, Barsoum S, Yu W, et al.: Human immunodeficiency virus type 1 induces persistent changes in mucosal and blood gammadelta $\mathrm{T}$ cells despite suppressive therapy. J Virol 2003;77:10456-10467.

257. Cheroutre H, Lambolez F, Mucida D: The light and dark sides of intestinal intraepithelial lymphocytes. Nat Rev Immunol 2011;11:445-456.

258. Strbo N, Alcaide ML, Romero L, et al.: Loss of intraepithelial endocervical gamma delta (GD) $1 \mathrm{~T}$ cells in HIV-infected women. Am J Reprod Immunol 2016;75: 134-145.

259. Alcaide ML, Strbo N, Romero L, et al: : Bacterial vaginosis is associated with loss of gamma delta $\mathrm{T}$ cells in the female reproductive tract in women in the Miami Women Interagency HIV Study (WIHS): A cross sectional study. PLoS One 2016;11:e0153045. 
260. Cimini E, Agrati C, D’Offizi G, et al.: Primary and chronic HIV infection differently modulates mucosal Vdeltal and Vdelta2 T-cells differentiation profile and effector functions. PLoS One 2015;10:e0129771.

261. Pauza CD, Poonia B, Li H, Cairo C, Chaudhry S: Gammadelta T cells in HIV disease: Past, present, and future. Front Immunol 2014;5:687.

262. Wong EB, Ndung'u T, Kasprowicz VO: The role of mucosal-associated invariant $\mathrm{T}$ cells in infectious diseases. Immunology 2017;150:45-54.

263. Zheng NN, McElrath MJ, Sow PS, et al.: Association between peripheral gammadelta T-cell profile and disease progression in individuals infected with HIV-1 or HIV-2 in West Africa. J Acquir Immune Defic Syndr 2011;57: $92-100$.

264. Glatzel A, Wesch D, Schiemann F, Brandt E, Janssen O, Kabelitz D: Patterns of chemokine receptor expression on peripheral blood gamma delta $\mathrm{T}$ lymphocytes: Strong expression of CCR5 is a selective feature of V delta $2 / \mathrm{V}$ gamma 9 gamma delta $\mathrm{T}$ cells. J Immunol 2002;168: 4920-4929.

265. Imlach S, Leen C, Bell JE, Simmonds P: Phenotypic analysis of peripheral blood gammadelta $\mathrm{T}$ lymphocytes and their targeting by human immunodeficiency virus type 1 in vivo. Virology 2003;305:415-427.

266. Wallace M, Scharko AM, Pauza CD, et al.: Functional gamma delta T-lymphocyte defect associated with human immunodeficiency virus infections. Mol Med 1997;3: $60-71$.

267. Soriano-Sarabia N, Archin NM, Bateson R, et al.: Peripheral Vgamma9Vdelta2 T Cells Are a Novel Reservoir of Latent HIV Infection. PLoS Pathog 2015;11:e1005201.

268. Cosgrove C, Ussher JE, Rauch A, et al.: Early and nonreversible decrease of CD161 ${ }^{++}$/MAIT cells in HIV infection. Blood 2013;121:951-961.

269. Fernandez CS, Kelleher AD, Finlayson R, Godfrey DI, Kent SJ: NKT cell depletion in humans during early HIV infection. Immunol Cell Biol 2014;92:578-590.
270. Spaan M, Hullegie SJ, Beudeker BJ, et al.: Frequencies of circulating MAIT cells are diminished in chronic HCV, $\mathrm{HIV}$ and HCV/HIV co-infection and do not recover during therapy. PLoS One 2016;11:e0159243.

271. Tabler CO, Lucera MB, Haqqani AA, et al.: CD4 ${ }^{+}$memory stem cells are infected by HIV-1 in a manner regulated in part by SAMHD1 expression. J Virol 2014;88:4976-4986.

272. Cashin K, Paukovics G, Jakobsen MR, et al.: Differences in coreceptor specificity contribute to alternative tropism of HIV-1 subtype C for CD4(+) T-cell subsets, including stem cell memory T-cells. Retrovirology 2014;11:97.

273. Buzon MJ, Sun H, Li C, et al.: HIV-1 persistence in $\mathrm{CD}^{+}$ $\mathrm{T}$ cells with stem cell-like properties. Nat Med 2014;20: 139-142.

274. Jaafoura S, de Goer de Herve MG, Hernandez-Vargas EA, et al.: Progressive contraction of the latent HIV reservoir around a core of less-differentiated CD4(+) memory T Cells. Nat Commun 2014;5:5407.

275. Ribeiro SP, Milush JM, Cunha-Neto E, et al.: The CD8(+) memory stem $\mathrm{T}$ cell (T(SCM)) subset is associated with improved prognosis in chronic HIV-1 infection. J Virol 2014;88:13836-13844.

276. Sedaghat AR, Siliciano JD, Brennan TP, Wilke CO, Siliciano RF: Limits on replenishment of the resting $\mathrm{CD}^{+}$ $\mathrm{T}$ cell reservoir for HIV in patients on HAART. PLoS Pathog 2007;3:e122.

277. Brodin J, Zanini F, Thebo L, et al.: Establishment and stability of the latent HIV-1 DNA reservoir. Elife 2016; 5:pii: e18889.

Address correspondence to: Shomyseh Sanjabi

Gladstone Institute of Virology and Immunology Gladstone Institutes 1650 Owens Street San Francisco, CA 94158

E-mail: shomyseh.sanjabi@gladstone.ucsf.edu 